\title{
Environmental and Radar Characteristics of Gargantuan Hail-Producing Storms
}

\author{
RACHEl E. GutierReZ ${ }^{\mathrm{a}}$ AND MATTHEw R. KumJiAN ${ }^{\mathrm{a}}$

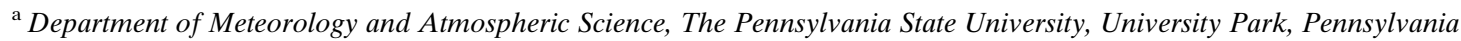

(Manuscript received 10 September 2020, in final form 30 April 2021)

\begin{abstract}
Storms that produce gargantuan hail (defined here as $\geq 6$ in. or $15 \mathrm{~cm}$ in maximum dimension), although seemingly rare, can cause extensive damage to property and infrastructure, and cause injury or even death to humans and animals. Currently, we are limited in our ability to accurately predict gargantuan hail and detect gargantuan hail on radar. In this study, we analyze the environmental and radar characteristics of gargantuan hail-producing storms to define the parameter space of environments in which gargantuan hail occurs, and compare environmental parameters and radar signatures in these storms to storms producing other sizes of hail. We find that traditionally used environmental parameters used for severe storm prediction, such as most unstable convective available potential energy (MUCAPE) and 0-6-km vertical wind shear, display considerable overlap between gargantuan hail-producing storm environments and those that produce smaller hail. There is a slight tendency for larger MUCAPE values for gargantuan hail cases, however. Additionally, gargantuan hail-producing storms seem to have larger low-level storm-relative winds and larger updraft widths than those storms producing smaller hail, implying updrafts less diluted by entrainment and perhaps maximizing the liquid water content available for hail growth. Moreover, radar reflectivity or products derived from it are not different from cases of smaller hail sizes. However, inferred mesocyclonic rotational velocities within the hail growth region of storms that produce gargantuan hail are significantly stronger than the rotational velocities found for smaller hail categories.
\end{abstract}

KEYWORDS: Hail; Radars/Radar observations

\section{Introduction}

Hailstorms are one of the costliest forms of severe weather. A single hailstorm can be responsible for billions of dollars worth of insured losses (Changnon 1999, 2008; Allen et al. 2015). For example, the San Antonio hailstorm of 2016 caused $\$ 1.36$ billion (U.S. dollars) in damage (Weather Forecast Office San Antonio 2016). In the summer of 2018, two Colorado hailstorms led to $\$ 3.2$ billion in damage (Forster 2019). One of those hailstorms was responsible for killing five animals and injuring several people at the Cheyenne Mountain Zoo (Childs 2018; Torres 2018). Similarly catastrophic events can occur globally, including two storms in Germany in 2013 that were responsible for $\$ 3.7$ billion in insured losses (MunichRe 2013).

Moreover, damages to property resulting from severe hail have increased in recent decades, in part owing to more homes and businesses being built in hail-prone regions, higher density of infrastructure, and more expensive materials (e.g., Roeder 2012; Brown et al. 2015; Allen et al. 2020). Though hailstone hardness characteristics can vary widely in convective storms (e.g., Giammanco et al. 2015), damage potential tends to increase with increasing impact kinetic energy, which is strongly related to hail size (Heymsfield et al. 2014). Because the damage potential of hail can be dependent on the size of the hailstones, predicting and detecting hail sizes is desirable.

Motivated by this desire, Blair et al. (2011) analyzed cases of reported giant hail $(>10 \mathrm{~cm}$ in maximum dimension; see also Table 1 for size naming conventions used here). Those authors found significant underprediction of hail size both in National Weather Service warnings and Storm Prediction

Corresponding author: Rachel E. Gutierrez, rachel.gutierrez@ noaa.gov
Center watches for these giant hail cases. Similarly, Blair et al. (2017) found that severe thunderstorm warnings tended to underestimate hail size for severe $(>2.5 \mathrm{~cm})$ and significantly severe $(>5.0 \mathrm{~cm})$ hail, and that the maximum hail size officially reported in the Storm Data database tended to be considerably lower than what was actually observed. Thus, a better understanding of storms that produce very large and potentially damaging hail is needed to improve our ability to forecast, detect, and warn for these hazards, and ultimately mitigate damages to property or life.

In this study, we focus on the extreme-high-end of hail size: the largest hailstones on record. Here, we explore "gargantuan" hail, a proposed size class for hailstones that are $\geq 6$ in. $(\geq 15 \mathrm{~cm}$ ) in maximum dimension (Table 1; see also Kumjian et al. 2020). Examples of gargantuan hailstones are shown in Fig. 1. Some of the most extreme damage can be caused by gargantuan hailstones because they can have large fall speeds and thus large impact kinetic energies (Fig. 2; see also Witt et al. 2018). Owing to their relative rarity, there is much less known about gargantuan hail events compared to those with smaller maximum sizes. As such, we present an analysis of environmental characteristics and radar signatures associated with each known gargantuan hail event.

The next section provides a background on previous studies on and the challenges associated with the prediction and detection of large hail events. Section 3 describes the datasets and methods used in the analysis. The results and discussion are in section 4 , followed by the summary and conclusions in section 5 .

\section{Background}

Hail grows in the updrafts of deep convective storms. As such, the updraft properties are thought to have important 
TABLE 1. Typical hail sizing convention (Storm Prediction Center 2019; Blair et al. 2011). Here, size refers to the hailstone's maximum dimension. We include a new proposed size category, "gargantuan," that includes hailstones $\geq 6$ in. or $15 \mathrm{~cm}$ in maximum dimension (Kumjian et al. 2020).

\begin{tabular}{lcc}
\hline \multicolumn{1}{c}{ Class } & Size (in.) & Size $(\mathrm{cm})$ \\
\hline Small/nonsevere & $<1.0$ & $<2.5$ \\
Severe & $\geq 1.0$ & $\geq 2.5$ \\
Significantly severe & $\geq 2.0$ & $\geq 5.0$ \\
Giant & $\geq 4.0$ & $\geq 10.0$ \\
Gargantuan & $\geq 6.0$ & $\geq 15.0$ \\
\hline
\end{tabular}

influences on hail production. Strong updrafts $\left(>20 \mathrm{~m} \mathrm{~s}^{-1}\right)$ are needed to support growing hailstones. However, studies have disagreed on whether an "especially strong" updraft is needed for significant growth (e.g., Knight and Knight 2005), or if faster updrafts are not as favorable for large hail, but rather broader regions of "moderate" (20-40 $\left.\mathrm{m} \mathrm{s}^{-1}\right)$ updrafts are important (Nelson 1983, 1987). Previous studies have found that if the updraft speed matches the hailstone fall speed, then hailstone residence time within the growth region could be maximized, favoring significant growth (e.g., Heymsfield 1983; Nelson 1983; Ziegler et al. 1983; Foote 1984; Rasmussen and Heymsfield 1987). Supercell storms in particular can provide favorable pathways for such a balance (e.g., Miller et al. 1988; Tessendorf et al. 2005; Dennis and Kumjian 2017; Kumjian and Lombardo 2020). However, it is not yet known if the mechanisms for large hail growth differ from the mechanisms of smaller hail growth (Nelson 1987) or if large hailstones do not require a "special set of circumstances," but are simply grown in the right place at the right time (Knight and Knight 2005).

The convective available potential energy (CAPE) can be used to crudely estimate updraft speed, according to parcel theory (e.g., Markowski and Richardson 2010). However, updraft speed is also affected by other factors not accounted for in parcel theory, including updraft width (e.g., Morrison 2016a,b), tilt (Parker 2010), entrainment (Zhang 2009; Peters et al. 2019), and, especially in supercell storms, dynamically driven accelerations associated with vertical vorticity and vertical wind shear (e.g., Peters 2020; Peters et al. 2019, 2020a,b). Indeed, although some studies have found that environments producing larger hail exhibited a slight tendency toward larger CAPE values (e.g., Edwards and Thompson 1998; Jewell and Brimelow 2009; Johnson and Sugden 2014; Púčik et al. 2015; Taszarek et al. 2017), there was also significant overlap in the distributions of CAPE values between the hail size categories used.

Given the propensity of supercells to produce very large hail (e.g., Blair et al. 2011, 2017; Kumjian et al. 2020), it is no surprise that increasing deep-layer shear also appears correlated to hail size categories in some studies (e.g., Johnson and Sugden 2014; Púčik et al. 2015), although again with significant overlap in the distributions of values. Similarly, low-level storm-relative helicity (SRH) did not display any significant differences between hail size categories in Johnson and Sugden (2014). Increased deep-layer shear also results in larger updraft widths (e.g., Dennis and Kumjian 2017; Trapp et al. 2017; Warren et al. 2017; Peters et al. 2019; Marion and Trapp 2019), owing to the resulting increase in low-level storm-relative wind magnitudes. All else being equal, greater updraft widths are conducive to greater hail growth owing to increased residence times (e.g., Nelson 1983; Dennis and Kumjian 2017; Kumjian et al. 2020), and possibly larger liquid water contents owing to less dilution from entrainment of dry environmental air (e.g., Peters et al. 2020a). Interestingly, Kumjian et al. (2019) found significantly greater low-level storm-relative wind magnitudes in 3 gargantuan hail cases compared to cases of accumulating small hail; those cases also had much greater instability, together implying stronger, larger updrafts. However, there was no comparison to other hail size categories in that study.

Radar is a powerful tool that can be used to monitor potentially hazardous storms. In an effort to improve the detection of impactful hail, Blair et al. (2011) analyzed radar signatures associated with giant hail-producing storms. Some signatures often used in an operational setting for warnings, like the radar reflectivity factor $\left(Z_{H}\right)$ values within the hail growth region (i.e., between $0^{\circ}$ and $-30^{\circ} \mathrm{C}$ ), did not provide any useful skill in distinguishing giant hail from smaller hail size categories. Similarly, despite the long-held belief that large $Z_{H}$ values at low levels are associated with larger hail sizes (e.g., Geotis 1963; Donaldson 1961; Aydin et al. 1986), more recent studies have reported smaller-than-expected $Z_{H}$ values at low levels in cases of very large hail (e.g., Witt et al. 2018; Ortega 2018; Kumjian et al. 2020), again suggesting that $Z_{H}$ values may not be reliable predictors of hail size. Vertically integrated $Z_{H}$ products, like the maximum estimated size of hail (MESH; Witt 1998), similarly have shown little skill in predicting the maximum hail size in storms (e.g., Ortega 2018; Witt et al. 2018; Murillo and Homeyer 2019).

Given the importance of the storm's updraft for hail production, radar signatures associated with the updraft may be useful. One such signature is the bounded weak-echo region (BWER), which represents a portion of the storm's updraft so strong that precipitation-sized particles have no ability to grow and/or fall through this region, resulting in a local minimum in $Z_{H}$ surrounded or "bounded" by larger $Z_{H}$ values. In theory, the BWER could serve as a proxy for updraft location and width. As such, Witt (1998) noted that better detection and quantification of BWERs could aid in hail forecasting. We develop such a technique for BWER quantification in this study.

Doppler radars also provide estimates of radial velocity, which some investigators have used for hail detection and hail sizing purposes (e.g., Witt 1998; Blair et al. 2011). Azimuthal shear in the radial velocities associated with storm midlevel mesocyclones, herein referred to as "rotational velocities," have shown some promise for hail-sizing efforts. Witt (1998) found a "moderate" relationship between rotational velocity and maximum reported hail size. Blair et al. (2011) found statistically significantly stronger rotational velocities in giant hail cases compared to "golf ball/hen egg" sized hail (4.5$5.1 \mathrm{~cm}$ ) cases, with an interquartile range of $20-29 \mathrm{~m} \mathrm{~s}^{-1}$ for the giant hail cases. In a case study of a gargantuan hail-producing storm, Witt et al. (2018) found very strong rotational velocities $\left(>50 \mathrm{~m} \mathrm{~s}^{-1}\right)$ at midlevels, and suggested observations of such large values could signal significant hail production. However, more cases are needed to explore whether the relationship 


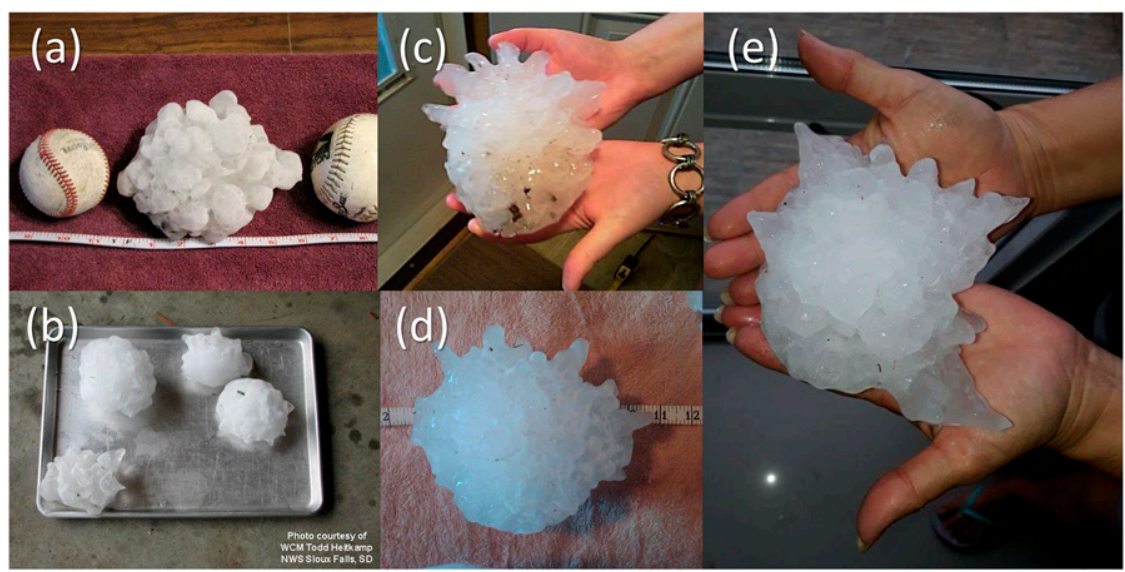

FIG. 1. Examples of gargantuan hailstones. (a),(b) Gargantuan hailstones from Wagner and Dante, SD, (NOAA/ NWS 2007). (c) Gargantuan hailstone from Wichita, KS, (NOAA/NWS 2010b). (d) Gargantuan hailstone from Vivian, SD, (NOAA/NWS 2010a). (e) Gargantuan hailstone from Villa Carlos Paz in Argentina (courtesy of Victoria Druetta).

between mesocyclone rotational velocity and hail size holds for the most extreme of hail sizes.

In summary, much is known about the basic mechanisms of hail growth and the storm modes and structures that support such growth. However, what factors set apart production of extreme hail sizes from smaller sizes remain unclear, which translates to an inability to operationally detect-let alone anticipate based on environmental cues-the significant threats associated with gargantuan hail. In particular, the main motivating questions guiding this research are as follows: Are gargantuan hailstones formed in extreme updrafts, or are they simply "flukes" in otherwise typical hailstorms? What are the environmental characteristics of gargantuan hail-producing storms, and how (if at all) do they differ from storms that produce smaller maximum hail sizes? Do gargantuan hail-producing storms have distinctive radar signatures that belie their capability of producing extreme hail? If so, can these signatures be used to warn for an enhanced hail threat?

With these questions in mind, this work will focus on evaluating the following hypotheses:

- Gargantuan hail-producing storms have strong, wide updrafts especially favorable for hail production.

- To support these favorable updrafts, gargantuan hail-producing storms form in environments with greater instability and vertical wind shear than those of storms producing smaller maximum hail sizes.

- Given the exceptionally large hail produced in these storms, they exhibit distinctive and extreme radar signatures, including $Z_{H}>50 \mathrm{dBZ}$ extending to high altitudes and anomalously large low-level $Z_{H}$ values.

\section{Data and methods}

In this study, we examine the 12 known gargantuan hail cases (Table 2 ). Although only 12 cases implies gargantuan hail is exceedingly rare, it is plausible that, like other very large hail, these events are severely underreported (e.g., Blair et al. 2011, 2017). The reports for all cases occurring in the United States can be found in the National Oceanic and Atmospheric Administration National Centers for Environmental Information (NOAA/NCEI) Storm Data database (NOAA National Centers for Environmental Information 2019). The Argentina case is documented in Kumjian et al. (2020). For each, we gather location, timing information, and reported hail size. A map of all U.S. gargantuan hail cases (Fig. 3) shows that they occur predominantly in the central Great Plains, extending from South Dakota to Texas. This area is consistent with hail climatologies developed using ground-based reports (e.g., Allen et al. 2017), as well as radar-based (Cintineo et al. 2012) and satellite-based (Bang and Cecil 2019) proxies for hail. The gargantuan hail events all occur between late spring

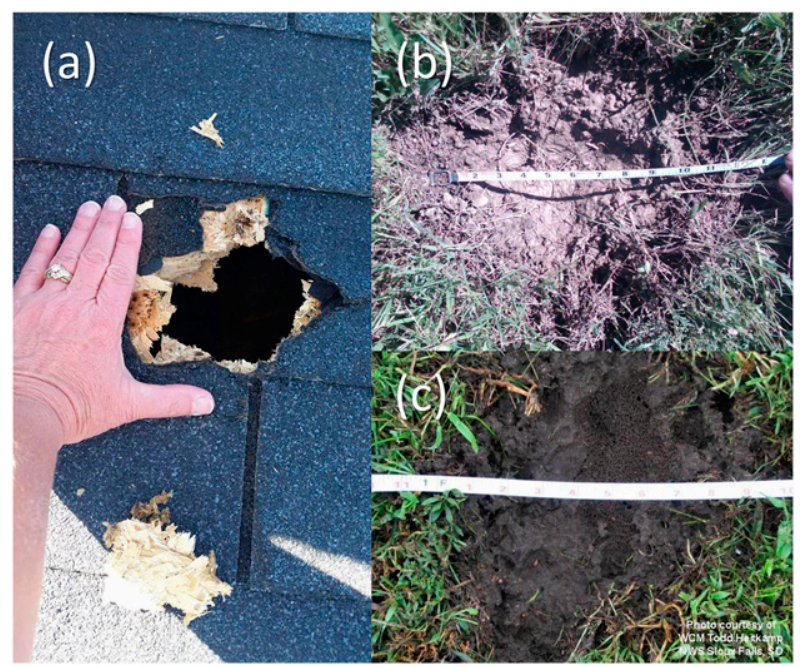

FIG. 2. Examples of gargantuan hail damage. (a) A hole in the roof of a home caused by gargantuan hail in Nisland, SD (Brunner 2015); (b),(c) craters in the ground caused by gargantuan hail in Vivian, SD, and Dante, SD, respectively (NOAA/NWS 2007, 2010a). 
TABLE 2. Gargantuan hail cases that are analyzed in this study. Here, "hail size" refers to the hailstone's maximum dimension.

\begin{tabular}{|c|c|c|c|c|c|c|}
\hline Case name & City, state & Date & Lat $\left({ }^{\circ}\right)$ & Lon $\left(^{\circ}\right)$ & Hail size (in.) & Hail size $(\mathrm{cm})$ \\
\hline Argentina & Carlos Paz, CB & 8 Feb 2018 & -31.42 & -64.49 & 7.10 & 18.03 \\
\hline Aurora & Aurora, NE & 22 Jun 2003 & 40.87 & -98.00 & 7.00 & 17.78 \\
\hline Dante & Dante, SD & 21 Aug 2007 & 43.03 & -98.20 & 6.88 & 17.48 \\
\hline El Reno & El Reno, OK & 31 May 2013 & 35.52 & -97.97 & 6.30 & 16.00 \\
\hline Gotebo & Gotebo, OK & 23 May 2011 & 35.09 & -98.87 & 6.00 & 15.24 \\
\hline Meadville & Meadville, MO & 24 May 2004 & 39.78 & -93.30 & 6.00 & 15.24 \\
\hline Nisland & Nisland, SD & 19 Jun 2015 & 44.65 & -103.5 & 6.00 & 15.24 \\
\hline Sunray & Sunray, TX & 12 Jun 2010 & 35.94 & -101.8 & 6.00 & 15.24 \\
\hline Timken & Timken, KS & 24 May 2011 & 38.47 & -99.18 & 6.00 & 15.24 \\
\hline Vivian & Vivian, SD & 23 Jul 2010 & 43.93 & -100.3 & 8.00 & 20.32 \\
\hline Wagner & Wagner, SD & 21 Aug 2007 & 43.08 & -98.30 & 6.13 & 15.57 \\
\hline Wichita & Wichita, KS & 15 Sep 2010 & 37.65 & -97.48 & 7.75 & 19.66 \\
\hline
\end{tabular}

and late summer, also consistent with existing hail climatologies (e.g., Mezher et al. 2012; Bruick et al. 2019; Bang and Cecil 2019).

\section{a. Environmental data}

To evaluate the first two hypotheses, we obtain information about the environments supporting gargantuan hail-producing storms. For most of the U.S. cases, we used the Rapid Update Cycle (RUC) or Rapid Refresh (RAP) model analyses (Benjamin et al. 2016) to obtain environmental information instead of observed soundings, which were often too far away in space and time (i.e., many hours and many hundreds of kilometers) and thus unrepresentative of environmental conditions supporting the gargantuan hail cases. The RUC/RAP has 13-km horizontal grid spacing, allowing us to pinpoint (to the nearest grid box) the gargantuan hailfall location. We selected model analyses at times $1-2 \mathrm{~h}$ prior to the hail event, following the methods in Kumjian et al. (2019). The Aurora and Meadville cases occurred prior to the RUC/RAP model availability, so we used the closest available observed soundings. For the Aurora case, we used the Omaha sounding at 0000 UTC 23 June 2003 (within $5 \mathrm{~min}$ and $100 \mathrm{~km}$ of the event), and for the Meadville case, we used the Topeka sounding at 0000 UTC 25 May 2004 (within 19 min and $136 \mathrm{~km}$ ). For the Argentina case, we use the values reported in Kumjian et al. (2020).

The RUC/RAP appeared to have positive biases in the surface temperature $(T)$ and dewpoint temperature $\left(T_{d}\right)$ values. For example, positively biased surface $T$ values produced shallow, strongly superadiabatic layers in the near-surface $T$ profile that we considered unrealistic. Such biases can significantly impact computed severe weather indices. Thus, using the surface pressure given by the RUC/RAP analysis and the full ${ }^{1} T$ and $T_{d}$ profiles, we linearly interpolated the slope above and below the designated surface pressure. This yielded surface $T$ and $T_{d}$ that were consistent with the slope of the profile aloft and also provided a more accurate representation of the surface values. This correction only applied to the $T$ and $T_{d}$; as such, the lowlevel winds were not affected. To evaluate these corrected $T$ and

\footnotetext{
${ }^{1}$ The full $T$ and $T_{d}$ profiles extend "below" the surface pressure (i.e., below ground).
}

$T_{d}$ values, we compare our modified soundings to any available observed soundings within $2 \mathrm{~h}$ and $100 \mathrm{~km}$. Only 2 cases met these criteria: El Reno (the 0000 UTC 1 June 2013 Norman, Oklahoma, sounding is $120 \mathrm{~min}$ and $67 \mathrm{~km}$ from the event) and Nisland (the 0000 UTC 20 June 2015 Rapid City, South Dakota, sounding is $60 \mathrm{~min}$ and $79 \mathrm{~km}$ from the event). The observed and modified $T$ are within $0.1^{\circ}$ and $1^{\circ} \mathrm{C}$ for the El Reno and Nisland cases, respectively. Though some substantial differences in the observed versus RAP/RUC $T_{d}$ profiles exist aloft (not shown), these will not affect the bulk indices computed herein.

Once satisfactory profiles were obtained, relevant severe storm parameters are calculated using MetPy (May et al. 2021). These include convective inhibition (CIN), 0-6-km bulk shear, and storm-relative helicity (SRH) over various depths. MUCAPE values were computed using an adaptation of the CM1 code (Bryan and Fritsch 2002), following Peters et al. (2020a). Additionally, we compute the significant hail parameter (SHIP). We use the vertical wind profiles and radar-estimated storm motion (described below) to construct storm-relative hodographs. For compositing, the hodographs are rotated such that the $x$ axis ( $u$-wind component) is aligned with the $0-6-\mathrm{km}$ vertical wind shear vector, following Parker (2014) and Kumjian et al. (2019).

\section{b. Radar}

We use radar observations to evaluate the first and third hypotheses above. Radar data for each case were gathered from the radar closest to the gargantuan hail report location, while still providing coverage at altitudes with temperatures between about $0^{\circ}$ and $-20^{\circ} \mathrm{C}$, or within the storm's hail growth region. For the U.S. cases, S-band WSR-88D radar level-II data were downloaded from the NOAA NCEI website. Data for the Argentina case come from their operational C-band RMA1 radar. ${ }^{2}$ Given that many of the cases occurred prior to the dual-polarization upgrade of the WSR-88D radar network, the radar analysis focuses primarily on single-polarization

\footnotetext{
${ }^{2}$ Data from RMA1 were obtained through Professor Paola Salio at the University of Buenos Aires from the Subsecretaria de Recursos Hídricos, Ministerio del Interior, Obras Publicas y Viviendia, Presidencia de la Nación, Argentina.
} 


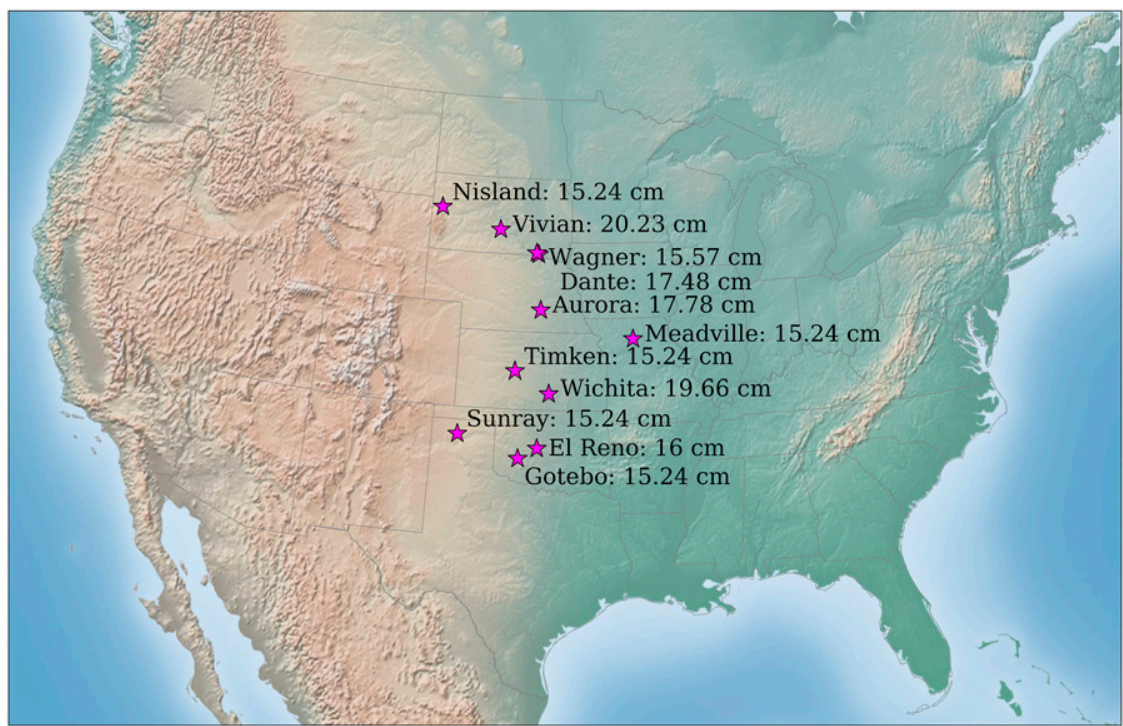

FIG. 3. Map of U.S. gargantuan hail cases (the Argentina gargantuan hail case is not included) with reported maximum dimensions.

variables: radar reflectivity factor at horizontal polarization (hereafter "reflectivity" or $\left.Z_{H}\right)$ and radial velocity $\left(V_{r}\right)$. The $V_{r}$ data were manually de-aliased using ARTview (Nick et al. 2016). Individual radar gates with velocity values that stood out/did not match with surrounding velocity pixels were considered erroneous/uncertain and were omitted from the analysis.

Using the Weather and Climate Toolkit (NOAA 2019), we tracked each storm's BWER for $\sim 1 \mathrm{~h}$ centered on the gargantuan hailfall time. The BWER was a reliable and consistent feature throughout the tracking time period. Best subjective judgment was used for estimating the center of the BWER, and we kept a consistent elevation angle that was within the hail growth region for the analysis. This tracking yielded storm motion for the gargantuan hail cases.

\section{Results and discussion}

\section{a. Environmental characteristics}

Using the soundings for each case, we aim to evaluate the first two hypotheses above and define the environmental parameter space (in terms of commonly used indices/parameters) of storms that produce gargantuan hail. Figure 4a shows the distribution of MUCAPE and 0-6-km shear values for each of the cases. For comparison, we also include data from the storms producing large accumulations of small hail (SPLASH) cases described in Kumjian et al. (2019), which yielded nearly the same number of cases as the gargantuan hail cases and characterize a substantially different hail threat. Additionally, the interquartile ranges of MUCAPE and shear values from environments for storms producing significantly severe hail from Blair et al. (2017) and marginally severe hail from Johnson and Sugden (2014) are included for comparison. The idea is to see if storms with different maximum reported hail sizes occupy different regions in the CAPE-shear parameter space.
All gargantuan hail cases have $>13 \mathrm{~m} \mathrm{~s}^{-1}$ of $0-6-\mathrm{km}$ bulk shear and $>2000 \mathrm{~J} \mathrm{~kg}^{-1}$ of MUCAPE, though 10 cases have $>20 \mathrm{~m} \mathrm{~s}^{-1}$ of bulk shear, and 8 cases have MUCAPE $>4400 \mathrm{~J} \mathrm{~kg}^{-1}$. All cases had between 1 and $14 \mathrm{~m} \mathrm{~s}^{-1}$ of $0-1-\mathrm{km}$ shear (not shown). Although both SPLASH and gargantuan hail cases occur in environments with a broad range of $0-6-\mathrm{km}$ bulk shear, SPLASH cases tend to have smaller MUCAPE $\left(<2000 \mathrm{~J} \mathrm{~kg}^{-1}\right)$. Similarly, the data from Blair et al. (2017) show that storms with hail maximum dimension reports ranging from 5.7 to $9.4 \mathrm{~cm}$ tend to occur in environments with somewhat smaller bulk shear values (interquartile range of values is $<25 \mathrm{~m} \mathrm{~s}^{-1}$ ) and less MUCAPE (interquartile range of values is $<4000 \mathrm{~J} \mathrm{~kg}^{-1}$ ) than those that produce gargantuan hail, though the distributions overlap somewhat. The cases of marginally severe (1.91-3.18-cm maximum dimension) hail reported in Johnson and Sugden (2014) exhibit even smaller interquartile range values of shear and MUCAPE. Thus, large $\left(>2000 \mathrm{~J} \mathrm{~kg}^{-1}\right)$ MUCAPE seems to be a necessary, but insufficient condition for gargantuan hail production. Further, sufficiently large 0-6-km shear is needed, presumably to support supercellular convection, but otherwise these cases occur across a wide range of shear values that do not stand out among environments that led to smaller maximum reported hail sizes.

The joint distribution of MUCAPE versus the 0-3-km SRH (Fig. 4b) reveals that the gargantuan hail cases occur in a wide range of $0-3-\mathrm{km} \mathrm{SRH}$ values, between $50 \mathrm{~m}^{2} \mathrm{~s}^{-2}$ and $400 \mathrm{~m}^{2} \mathrm{~s}^{-2}$, with one case (Wichita) exceeding $400 \mathrm{~m}^{2} \mathrm{~s}^{-2}$. For $0-1-\mathrm{km} \mathrm{SRH}$ (not shown), all cases were between 5 and $200 \mathrm{~m}^{2} \mathrm{~s}^{-2}$, with most cases occurring with $<150 \mathrm{~m}^{2} \mathrm{~s}^{-2}$. Figure $4 \mathrm{~b}$ also shows that $\mathrm{SRH}$ does not distinguish the gargantuan hail environments from those of SPLASH cases; the Johnson and Sugden (2014) marginally severe cases tend to occur for smaller SRH values (which makes sense, given the possibility that some of these marginal cases were nonsupercellular). The Blair et al. (2017) 

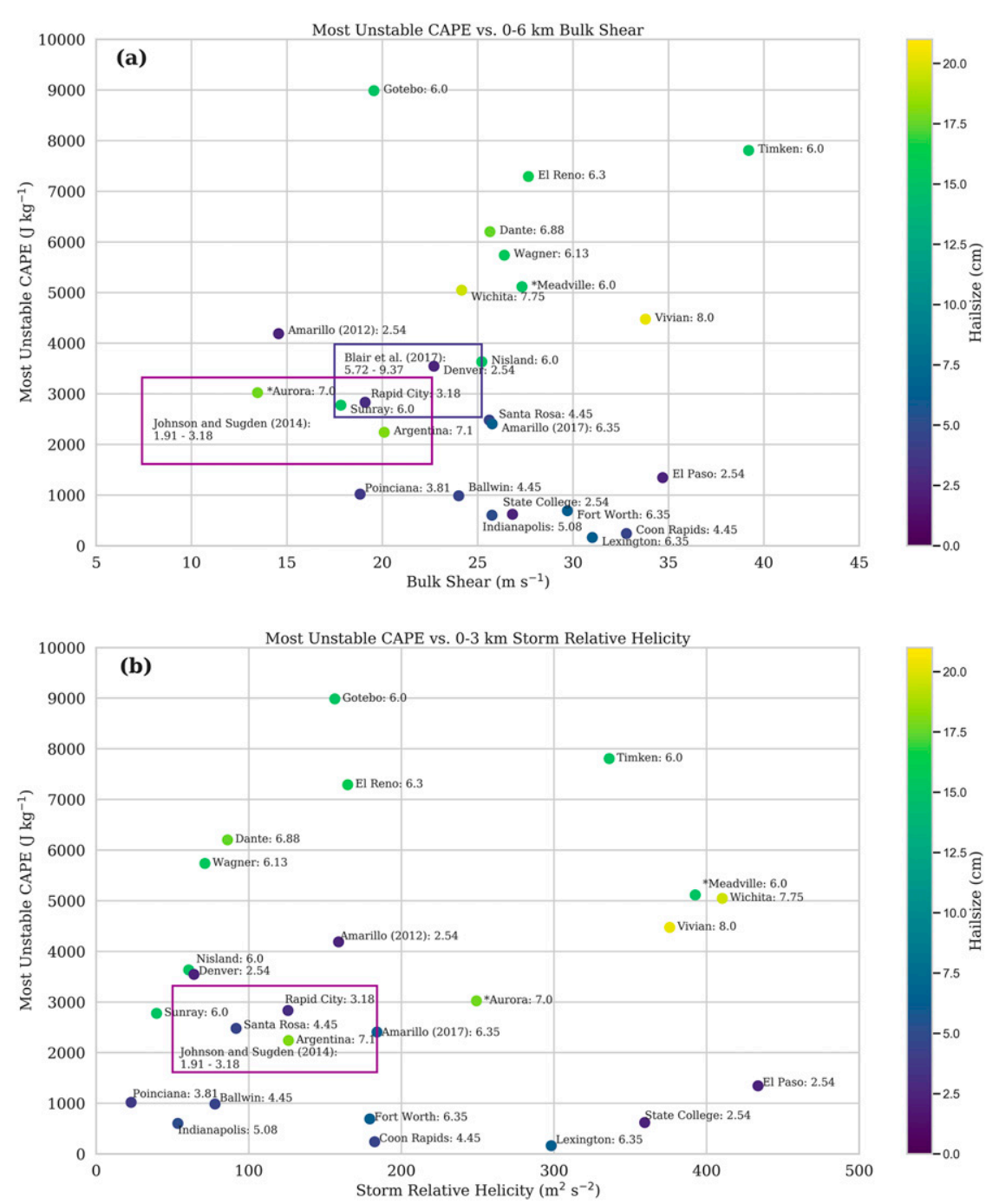

FIG. 4. (a) MUCAPE vs 0-6-km bulk shear for both the SPLASH and gargantuan hail cases. Results from Blair et al. (2017) are shown in the blue box with the corresponding range of hail sizes. Results from Johnson and Sugden (2014) are shown in the purple box. (b) MUCAPE vs 0-3-km SRH for both the SPLASH and gargantuan hail cases. Results from Johnson and Sugden (2014) are shown in the purple box. Asterisks denote cases in which observed soundings were used.

study does not present SRH values and thus these are unavailable for comparison in Fig. $4 \mathrm{~b}$.

Thus, gargantuan hail-producing storms apparently can occur in environments generally that have larger MUCAPE than other classes of maximum hail sizes, with somewhat larger bulk shear values that display overlap with other size classes. The larger MUCAPE values would suggest stronger updrafts, and the larger bulk shear would suggest wider updrafts, consistent with our first two hypotheses.

To explore the connection more robustly, we calculate the entrainment CAPE (ECAPE) for these environments following Peters et al. (2020a). ECAPE is a more accurate predictor of updraft maximum speed (at least in supercells) than MUCAPE (e.g., Peters et al. 2020a) because it accounts for the effects of entrainment on the updraft strength. Storms in environments in which ECAPE and MUCAPE values are similar suggest less entrainment, and, therefore, stronger updrafts with potentially greater liquid water contents. Figure 5 compares the ECAPE and MUCAPE values for the gargantuan hail cases to those from a large dataset of severe storms from Peters et al. (2019). The Peters et al. (2019) dataset clearly shows that environments with larger effective bulk wind difference are closer to the "one-to-one" line between ECAPE and MUCAPE. The gargantuan hail cases appear even closer to the one-to-one line than the cloud of points from Peters et al. (2019), suggesting the updrafts forming in those environments may be comparatively less affected by entrainment, and therefore favorable for efficient hail production. 


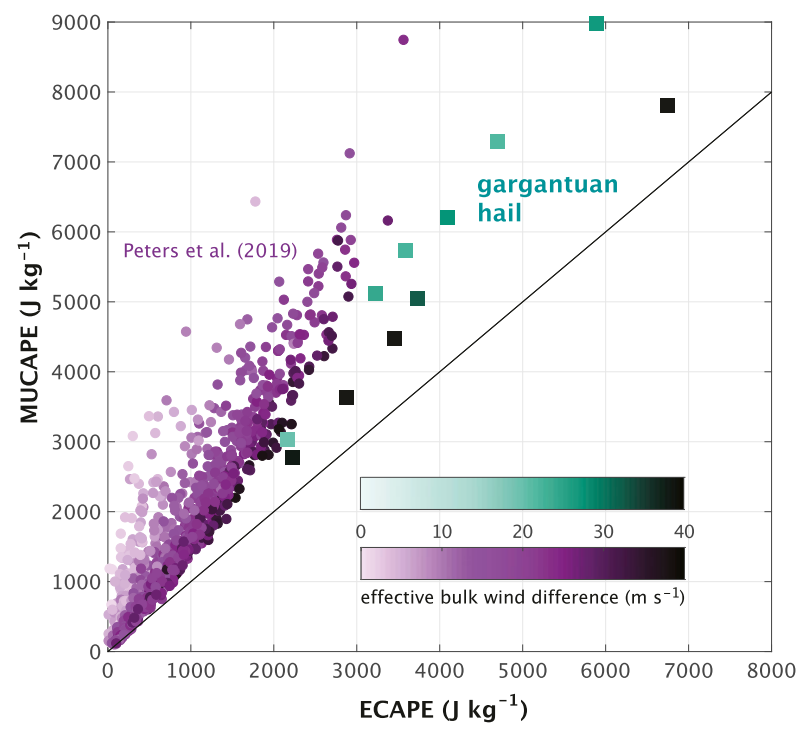

FIG. 5. The relationship between ECAPE and MUCAPE for the environments of storms detailed in Peters et al. (2019) (purple circle markers) and the gargantuan hail cases (turquoise square markers). The shading of each marker is indicative of the effective bulk wind difference, as in Peters et al. (2019), shaded according to the inset color scales. The one-to-one line implies no dilution of the updraft by entrainment (i.e., ECAPE = MUCAPE).

Recent work by Dennis and Kumjian (2017) and Kumjian and Lombardo (2020) has shown that the vertical profiles of storm-relative winds can exert a substantial influence on supercell hail production. To further explore the details of the vertical wind profiles for these cases, we construct a composite rotated storm-relative hodograph for the gargantuan hail cases (Fig. 6a). The composite hodograph reveals veering stormrelative winds in the lowest few $\mathrm{km}$, followed by predominantly unidirectional shear aloft, characteristic of hodographs in supercellular environments (e.g., Markowski and Richardson 2010; Parker 2014). Compared to the iconic "quarter-circle" supercell hodograph (e.g., Weisman et al. 2000), the lowest $2-\mathrm{km}$ portion of the gargantuan hail composite hodograph is somewhat enlarged (i.e., enhanced storm-relative wind magnitudes), and the storm-relative winds above $6 \mathrm{~km}$ have a component to the right of the $0-6-\mathrm{km}$ shear vector. Enlarged low-level hodographs can be favorable for tornadogenesis (e.g., Coffer and Parker 2017); indeed, all but three of the gargantuan hail-producing storms were tornadic, although only one (El Reno) was significantly tornadic (EF2+; NOAA National Centers for Environmental Information 2019). The \pm 1 standard deviation error bars demonstrate considerable spread among the cases, however, so caution is warranted against an overly literal interpretation of the composite.

Figure 6b compares the gargantuan hail composite stormrelative hodograph to the composite for SPLASH cases from Kumjian et al. (2019). Despite similar shapes in the lowest few $\mathrm{km}$, the gargantuan hail cases have much stronger stormrelative wind magnitudes in this layer. This is further supported with the mean vertical profiles of storm-relative winds
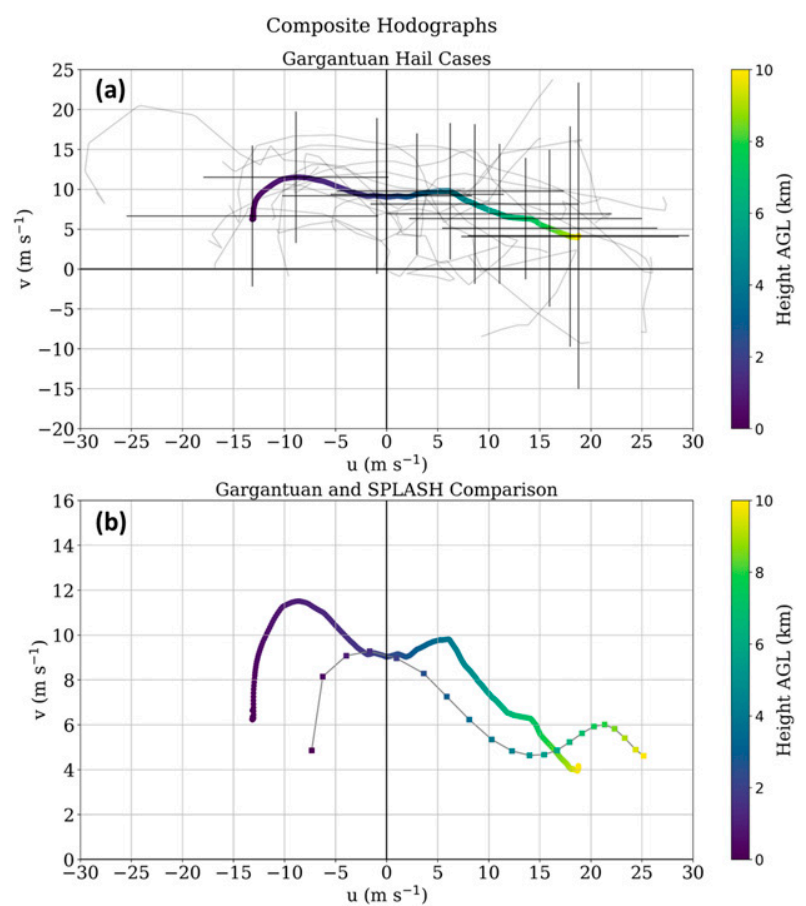

FIG. 6. (a) Rotated, storm-relative composite hodograph for all gargantuan hail cases. Black bars represent the \pm 1 standard deviation in $u$ and $v$ storm-relative winds at $1-\mathrm{km}$ intervals. Thin gray lines show hodographs from each case. (b) Rotated, storm-relative composite hodographs for gargantuan hail cases (thick line) and SPLASH cases (thin line with markers every $0.5 \mathrm{~km}$ in altitude). Altitude given as color (scale to right). Note that the $y$-axis changes between the two panels.

shown in Fig. 7. Especially below $2 \mathrm{~km}$, gargantuan hail cases have, on average, larger storm-relative wind magnitudes than SPLASH cases. This trend reverses above about $5 \mathrm{~km}$. We used a bias-corrected-and-accelerated bootstrapping technique (Efron and Tibshirani 1993) with 1000 samples to estimate the $95 \%$ confidence interval about the mean storm-relative wind profiles at each height; these are shown as shaded bands in Fig. 7. Below about $1.5 \mathrm{~km}$, the confidence intervals do not overlap, implying statistically significantly larger storm-relative wind speeds for gargantuan hail cases compared to SPLASH cases. All else being equal, larger storm-relative wind magnitudes at low levels can lead to larger updraft widths (e.g., Warren et al. 2017; Peters et al. 2019, 2020b), which are known to promote increased hail production owing to increased trajectory residence times (e.g., Nelson 1983; Dennis and Kumjian 2017; Kumjian and Lombardo 2020). Again, however, note that the small sample sizes and large spread of the data (i.e., the $95 \%$ confidence interval bands exhibit various degrees of overlap throughout the profile).

Compared to the SPLASH storm-relative hodograph, the gargantuan storm-relative hodograph exhibits a shift suggestive of larger storm motions along and to the right of the $0-6-\mathrm{km}$ shear vector. This is despite the similar deep-layer shear magnitudes seen in Fig. 4a. One explanation could be the larger MUCAPE: stronger updrafts and consequently greater 


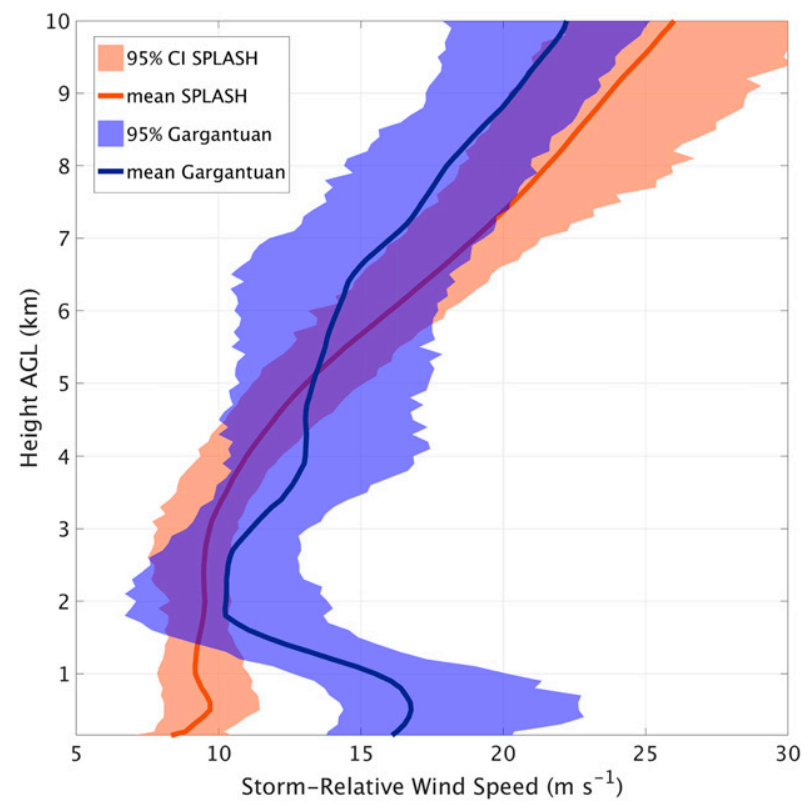

FIG. 7. Storm-relative winds as a function of height for both gargantuan (blue) and SPLASH (orange) cases. The mean profiles are shown in thick solid lines, and the shaded bands represent the bootstrapped $95 \%$ confidence interval about the means.

precipitation production could lead to stronger cold pools, and thus increased storm motion over the SPLASH cases. Indeed, six of the gargantuan hail-producing storms passed over an ASOS/AWOS station near the time of gargantuan hailfall; the cold pools sampled revealed significant $T$ decreases ranging between $6^{\circ}$ and $10.6^{\circ} \mathrm{C}$ (not shown). Additionally, compared to the Bunkers et al. (2000) hodograph-based estimate of storm motion, observed storm motions for the gargantuan hail cases have a shift rightward by about $30^{\circ}$ (Fig. 8). Bunkers (2018) suggested this tendency may arise for storms with increased $\mathrm{SRH}$ and/or greater vertical wind shear at low levels. Though not seen in our analysis of $0-3-\mathrm{km}$ SRH nor $0-1-\mathrm{km}$ SRH, gargantuan hail cases on average do have larger vertical wind shear in the lowest $2 \mathrm{~km}$ than the SPLASH cases (see Fig. 6).

Finally, we calculate the significant hail parameter (SHIP) for all gargantuan hail cases (Fig. 9). SHIP is a composite parameter used by the Storm Prediction Center (SPC) that includes measures of instability, low-level moisture, midlevel lapse rates, midlevel parcel buoyancy, and 0-6-km shear, and is used operationally to discriminate between environments favorable for significantly severe hail versus smaller hail. Additional information can be found on the SPC help page for SHIP. ${ }^{3}$ The SPC found that SHIP values between 1.5 and 2 are common for significantly severe hail, whereas hail $\geq 6.35 \mathrm{~cm}$ in maximum dimension tends to occur in environments with SHIP values ranging between 1.1 and 4 (Storm Prediction Center 2019). SHIP values for gargantuan hail cases range from about 1.5 to about 7 with a median of 2.9 and mean of 3.9 ,

\footnotetext{
${ }^{3}$ https://www.spc.noaa.gov/exper/mesoanalysis/help/help\sigh.html.
}

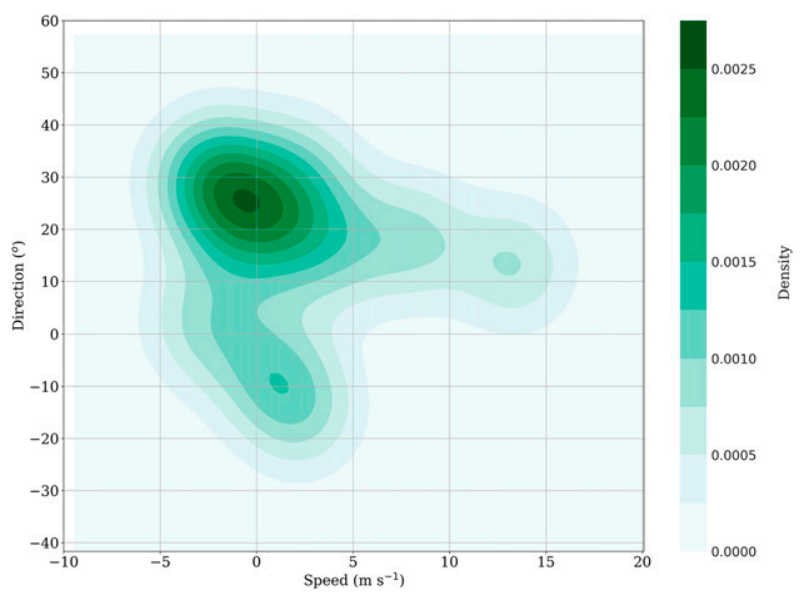

FIG. 8. Two-dimensional kernel density estimate of the observed storm motion minus the calculated right-moving Bunkers storm motion in terms of speed (on the abscissa) and direction (along the ordinate axis). The shading represents the probability density, according to the scale.

exhibiting significant overlap with SHIP values for smaller hail. Thus, although consistent with significantly severe hail, SHIP values are not otherwise more extreme for these gargantuan hail events.

\section{b. Radar characteristics}

Next, we evaluate the radar-observed characteristics of gargantuan hail-producing storms to evaluate our third hypothesis. We constructed composite $Z_{H}$ swaths (i.e., the maximum $Z_{H}$ in a radar conical scanning volume scan passing over a $1 \mathrm{~km} \times 1 \mathrm{~km}$ box; owing to their large distances from radar, we used $2 \mathrm{~km} \times 2 \mathrm{~km}$ grid boxes for the Vivian and Wagner/Dante cases) for a total of $1-2 \mathrm{~h}$, centered on the time of gargantuan hailfall. As evident from the $Z_{H}$ swaths (Fig. 10), assuming accurate reported locations, gargantuan hail typically falls outside of the maximum $Z_{H}$ region. Figure 11 shows kernel density estimates (e.g., Peel and Wilson 2008; Anderson-Frey et al. 2016) of the maximum $Z_{H}$ to occur anywhere within the swath and the maximum $Z_{H}$ to occur at the gargantuan hailfall location, using all cases. There is an offset of about $8.5 \mathrm{~dB}$ between the $Z_{H}$ at the gargantuan hailfall location and the maximum $Z_{H}$ to occur in the storm, with the storm-maximum $Z_{H}$ mode at $73.5 \mathrm{dBZ}$ and the maximum $Z_{H}$ at the hailfall location of $65 \mathrm{dBZ}$. Figure 10 and 11 show that composite $Z_{H}<60 \mathrm{dBZ}$ is possible at the gargantuan hailfall location. That the largest hailfalls outside the region of maximum $Z_{H}$ is consistent with its expected fallout location from the updraft and subsequent size sorting of hydrometeors (e.g., Browning and Foote 1976). These storms do display large $Z_{H}$ values, though not particularly extreme relative to other hailstorms (e.g., see discussions in Kumjian et al. 2019 and Allen et al. 2020).

Next, we analyzed $Z_{H}$ vertical profiles to assess the vertical structure of storms producing gargantuan hailstones. Our $Z_{H}$ vertical profiles are constructed using a $5 \mathrm{~km} \times 5 \mathrm{~km}$ grid box centered on the gargantuan hailfall location, for all radar elevations, at the time of hailfall. Radar beam heights are 


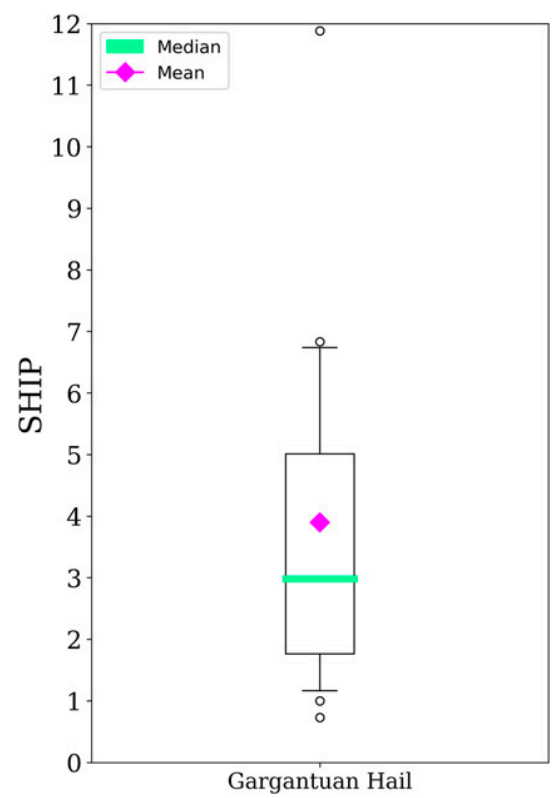

FIG. 9. Boxplot of the significant hail parameter (SHIP) for all gargantuan hail cases. The teal bar is the median, the magenta diamond is the mean, the box is the interquartile range, the whiskers extend to the 10th and 90th percentiles, and the circles are the outliers.

calculated based on standard atmospheric refraction (Doviak and Zrnić 1993). A linear interpolation was performed to retrieve the temperatures that correspond to the derived radar beam heights using the RUC/RAP soundings. The data from each case were then binned into $5^{\circ} \mathrm{C}$ increments, from $25^{\circ}$ to $-50^{\circ} \mathrm{C}$. The Argentina case is not included in this analysis because the RMA1 radar operates at $\mathrm{C}$ band, and it did not sample the depth of the storm sufficiently to create an informative vertical profile of $Z_{H}$. Figure 12 shows the distribution of $Z_{H}$ values for all cases at all levels. We find that $Z_{H}>$ $45 \mathrm{~dB} Z$ for all cases up to about $-40^{\circ} \mathrm{C}$, which includes the entire hail growth region. Ortega (2018) examined vertical $Z_{H}$ profiles for different categories of hail maximum dimension. His results suggest that distributions of $Z_{H}$ values at each altitude shift to greater values for larger hail size categories, though overlap exists for these distributions. For the largest hail size category in that study $(>5 \mathrm{~cm}$ in maximum dimension), $Z_{H}$ ranged between 50 and $60 \mathrm{~dB} Z$ for the depth of the profile. Our results show that gargantuan hail storms have similar if not slightly lower values throughout the profile, suggesting that vertical profiles of $Z_{H}$ do not provide utility for distinguishing gargantuan hail from smaller sizes.

The analysis of maximum $Z_{H}$ values and vertical profiles of $Z_{H}$ throughout the storm does not point to distinctive signals compared to other hail size classes, which is inconsistent with our third hypothesis. Given the importance of broad updraft regions for hail growth described in the introduction, and the results from the environmental analysis, however, we might expect radar signatures more directly related to updraft properties to be useful. As such, we developed an algorithm that quantifies the BWER area as a proxy for updraft breadth. BWERs are found throughout the hail growth region for every gargantuan hail case. In this way, we can gather a characteristic sample of BWER areas that represent the gargantuan hail cases that may be able to help with forecasting/nowcasting efforts. Examples are shown in Fig. 13. Note that the BWER typically is only a fraction of the overall updraft breadth. For reference, we consider the standard "quarter-circle" hodograph simulated supercell (Weisman et al. 2000), composited for $1 \mathrm{~h}$ during its mature phase (see Dennis and Kumjian 2017). In this simulation, the BWER occupies only about $25 \%$ of the area encompassed by the $10 \mathrm{~m} \mathrm{~s}^{-1}$ contour in the hail growth region (i.e., at $7.625 \mathrm{~km}$, where the in-updraft temperature is $\left.-18^{\circ} \mathrm{C}\right)$. The simulated $>10 \mathrm{~m} \mathrm{~s}^{-1}$ updraft area $\left(74 \mathrm{~km}^{2}\right)$ is consistent with those found in a large number of simulated supercells in wide range of environments in other recent work (Peters et al. 2019). Thus, the reported BWER areas in the hail growth region will be taken as crude proxies for roughly a quarter of the updraft area.

To calculate BWER area, we first identified the BWER through visual inspection of plan position indicator (PPI) scans through the storm's midlevels. We then gathered radial profiles of $Z_{H}$, the moving average (over 2 gates) of $Z_{H}$, and the standard deviation of this moving average for azimuths that intersect this region. We selected the radials that had a significant drop in $Z_{H}$ with range, and then a return to higher $Z_{H}$ values. The "beginning" and "end" radials that exhibit this significant drop and subsequent rise in $Z_{H}$ helped mark the approximate edges of the BWER. Then, we used a combination of manual inspection and a 2-dB flag in the standard deviation to mark the edges of the BWER; standard deviations $\leq 2 \mathrm{~dB}$ are within the measurement error and/or noise (Ryzhkov et al. 2005). Radial perturbations outside of typical measurement errors/noise could be indicative of large $Z_{H}$ gradients characteristic of BWER edges. We then calculated the area of the BWER using these identified BWER bounds and radar geometry. This algorithm worked well for most cases, but underestimated the BWER areas for the Sunray, Gotebo, and Meadville cases. The BWER algorithm had worse performance when the BWER had a strange shape or had deformations, or if the $Z_{H}$ gradient surrounding the BWER was weak. We focus on analyzing the hail growth region at three times: the scans before, during, and after gargantuan hailfall. We take data from three elevation angle scans that intersect the hail growth region, approximately ${ }^{4}$ between $0^{\circ}$ and $-20^{\circ} \mathrm{C}$, for all cases. Although the Argentina case did have a BWER, it is not included in the analysis because the operational radar did not have sufficient sampling aloft to track it in time or height.

Figure 14 shows the observed BWER areas for each case, time, and elevation. The BWER area is consistent with time and elevation, implying that the updraft is relatively steady at the times adjacent to the gargantuan hailfall. BWER areas ranged from 20 to $40 \mathrm{~km}^{2}$, with a median of $20.8 \mathrm{~km}^{2}$ and a

\footnotetext{
${ }^{4}$ The range of temperatures for the lowest elevation is $2.5^{\circ}$ to $-6.3^{\circ} \mathrm{C}$, for the middle elevation is $-7.1^{\circ}$ to $-14.8^{\circ} \mathrm{C}$, and for the highest elevation is $-17^{\circ}$ to $-28.4^{\circ} \mathrm{C}$.
} 


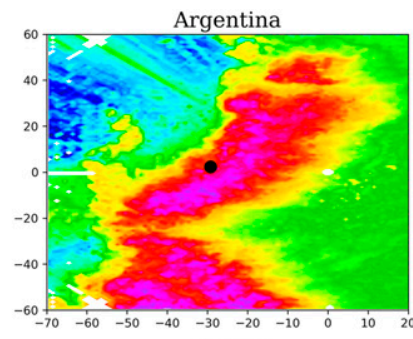

El Reno

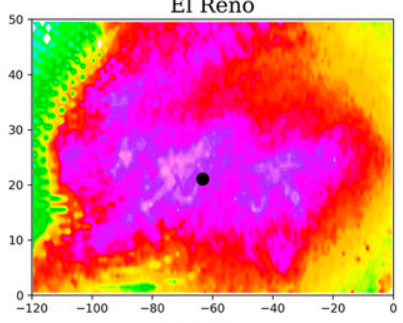

Meadville
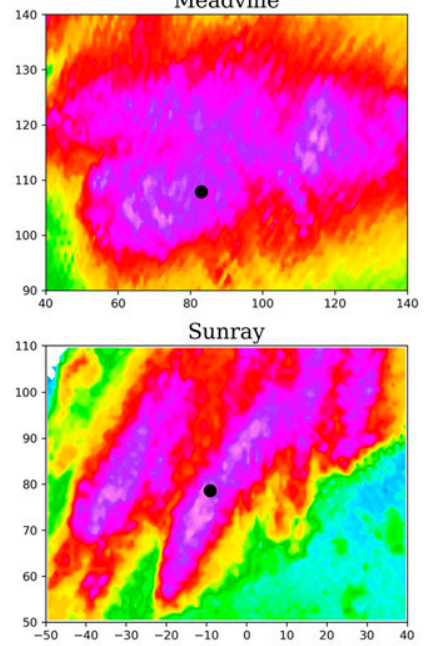

Vivian
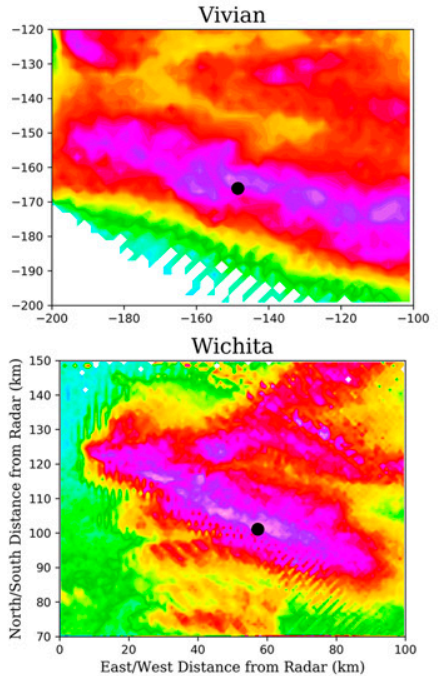

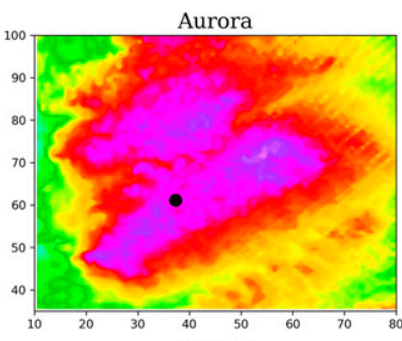

Gotebo

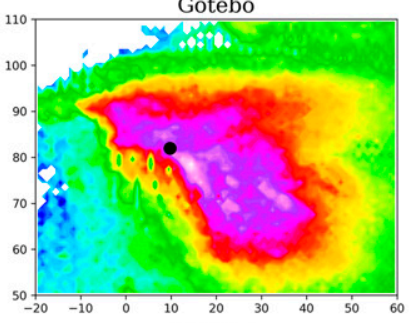

Nisland

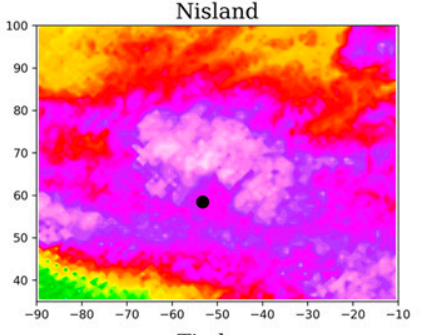

Timken
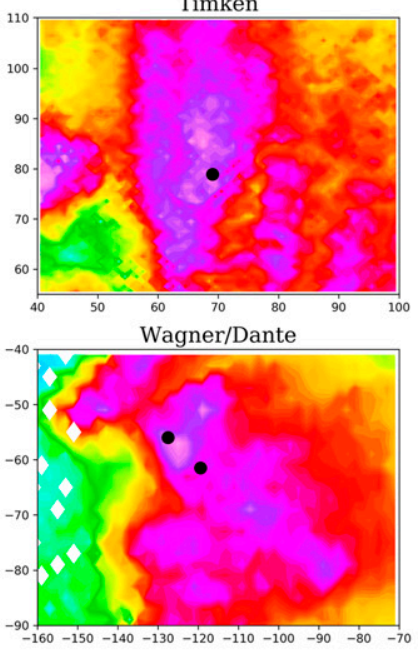

$-20$

$-10$

60

70

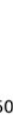

40

10

FIG. 10. Composite $Z_{H}$ swaths for all hail cases. The large black dot on the swath represents the location of the gargantuan hailfall. Note that the domain sizes change in each panel. 


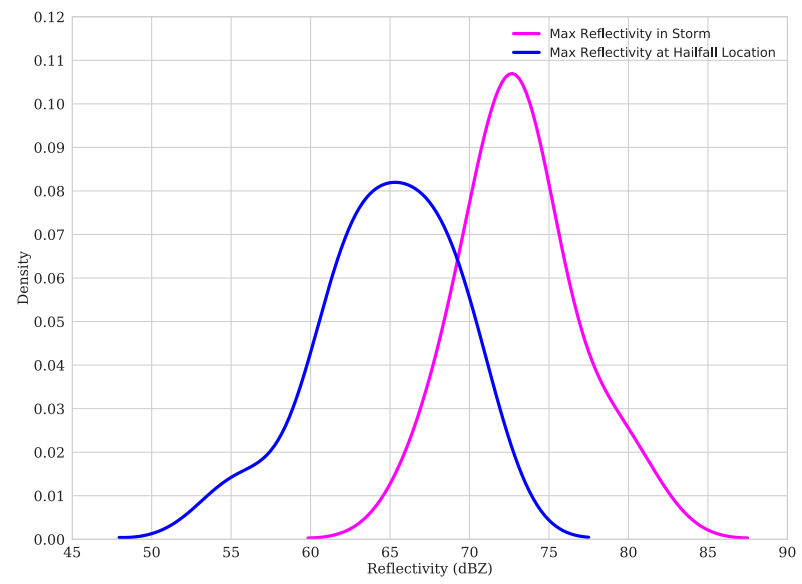

FIG. 11. Kernel density estimate of the maximum reflectivity to occur at the gargantuan hailfall location (blue) and the maximum reflectivity to occur anywhere in the storm (magenta). The bandwidth used is $2.5 \mathrm{~dB}$.

mean of $28.7 \mathrm{~km}^{2}$. Recall that, in the simulated supercell, the $>10 \mathrm{~m} \mathrm{~s}^{-1}$ updraft area was about 4 times that of the BWER area within the hail growth region. Extrapolating the BWER-updraft area relationship to these observations suggests median and mean updraft areas of about 83 and $115 \mathrm{~km}^{2}$, respectively. Assuming circular updrafts, this corresponds to effective updraft diameters of $10-12 \mathrm{~km}$, on the upper end of supercells simulated by Peters et al. (2019). We again caution that these should be considered crude estimates. Direct comparisons of BWER areas between storms with smaller maximum hail sizes is warranted in future studies.

Finally, we explore the rotational velocities of the mesocyclone within the hail growth region. Blair et al. (2011) found that there is a general increase of mean rotational velocity with hail size category (see their Fig. 14). We extend their analysis to include gargantuan hail cases. The same times and elevations that were used for the BWER area calculations are used here, though the data used do extend slightly outside of the BWER area (i.e., azimuth and range) to ensure that we capture the entire velocity signature associated with the mesocyclone.

To obtain the rotational velocities, we obtained the maximum velocity and the minimum velocity associated with the mesocyclone (for the three times and three elevations), and computed $V_{\text {rot }}$ as follows:

$$
V_{\text {rot }}=\left(\left|V_{\min }\right|+\left|V_{\max }\right|\right) / 2,
$$

where $V_{\min }\left(\mathrm{m} \mathrm{s}^{-1}\right)$ is the minimum velocity and $V_{\max }\left(\mathrm{m} \mathrm{s}^{-1}\right)$ is the maximum velocity (see also Blair et al. 2011; Witt et al. 2018). This equation is valid if the storm has both inbound and outbound velocities, which was true for all of our cases. The Argentina case was also omitted from this analysis owing to inconsistent elevation angles in the scans before/during/after gargantuan hailfall.

Figure 15 shows the distribution of rotational velocities within the hail growth region for times before, during, and after

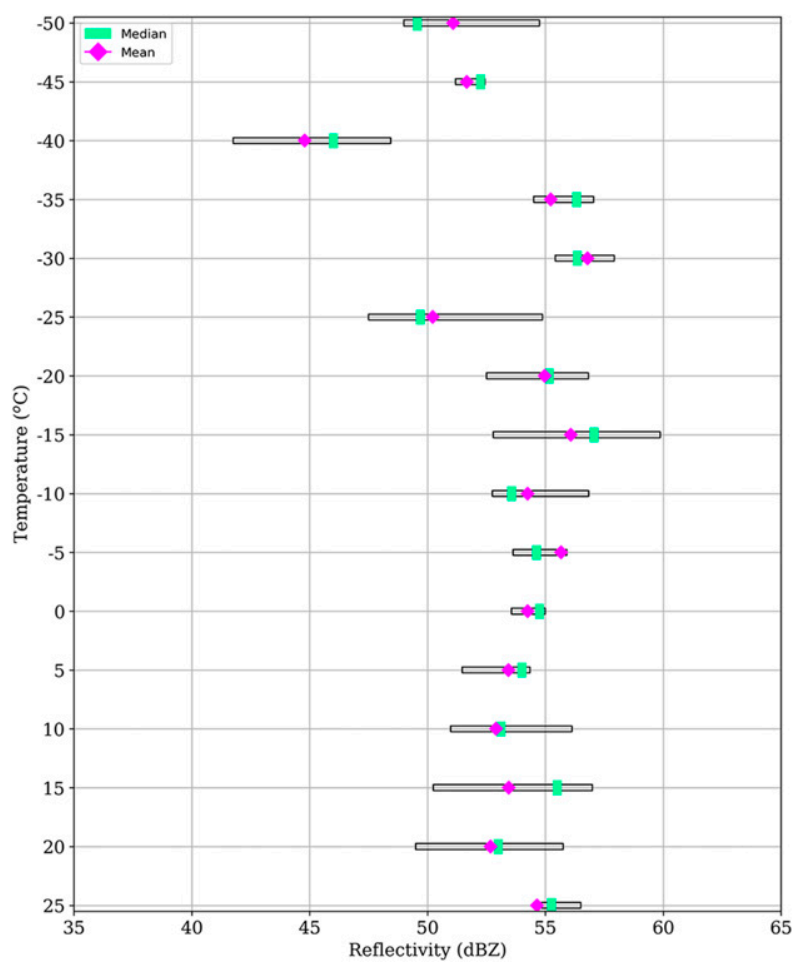

FIG. 12. Profile of $Z_{H}$ for a $5 \mathrm{~km} \times 5 \mathrm{~km}$ grid box centered on the gargantuan hailfall location as a function of temperature from RUC/RAP soundings, binned in $5^{\circ} \mathrm{C}$ increments. The teal bars are medians, the magenta diamonds are means, and the boxes are the interquartile ranges.

gargantuan hail. The largest rotational velocity is $48.1 \mathrm{~m} \mathrm{~s}^{-1}$ (associated with the El Reno case), ${ }^{5}$ the smallest rotational velocity is $14.0 \mathrm{~m} \mathrm{~s}^{-1}$ (Gotebo), and the median and mean rotational velocity for all cases is 31.3 and $31.7 \mathrm{~m} \mathrm{~s}^{-1}$, respectively. These values are consistent in time and altitude, implying consistent mesocyclone strength around the time of gargantuan hailfall. The interquartile range of rotational velocities for all gargantuan hail cases at all times and elevations considered is about $25-40 \mathrm{~m} \mathrm{~s}^{-1}$, which generally is larger than the $20-29 \mathrm{~m} \mathrm{~s}^{-1}$ interquartile range of peak rotational velocities reported in Blair et al. (2011) for giant hail. Further, the distribution of peak rotational velocities for all gargantuan hail cases features an interquartile range between 34.6 and $46.9 \mathrm{~m} \mathrm{~s}^{-1}$, entirely separated from the peak rotational velocities for giant hail cases in Blair et al. (Fig. 15b). These results extend those of Blair et al. (2011) and support the notion that increased rotational velocities suggest the potential for larger hail. This finding also supports our third hypothesis, in that mesocyclone rotational velocities in gargantuan hail-producing

\footnotetext{
${ }^{5}$ The maximum rotational velocity values found here are somewhat lower than those reported in Witt et al. (2018) for this case, because those authors investigated the rotational velocities throughout the duration of the storm, whereas here we focus only on the times around when the gargantuan hailfall was reported.
} 

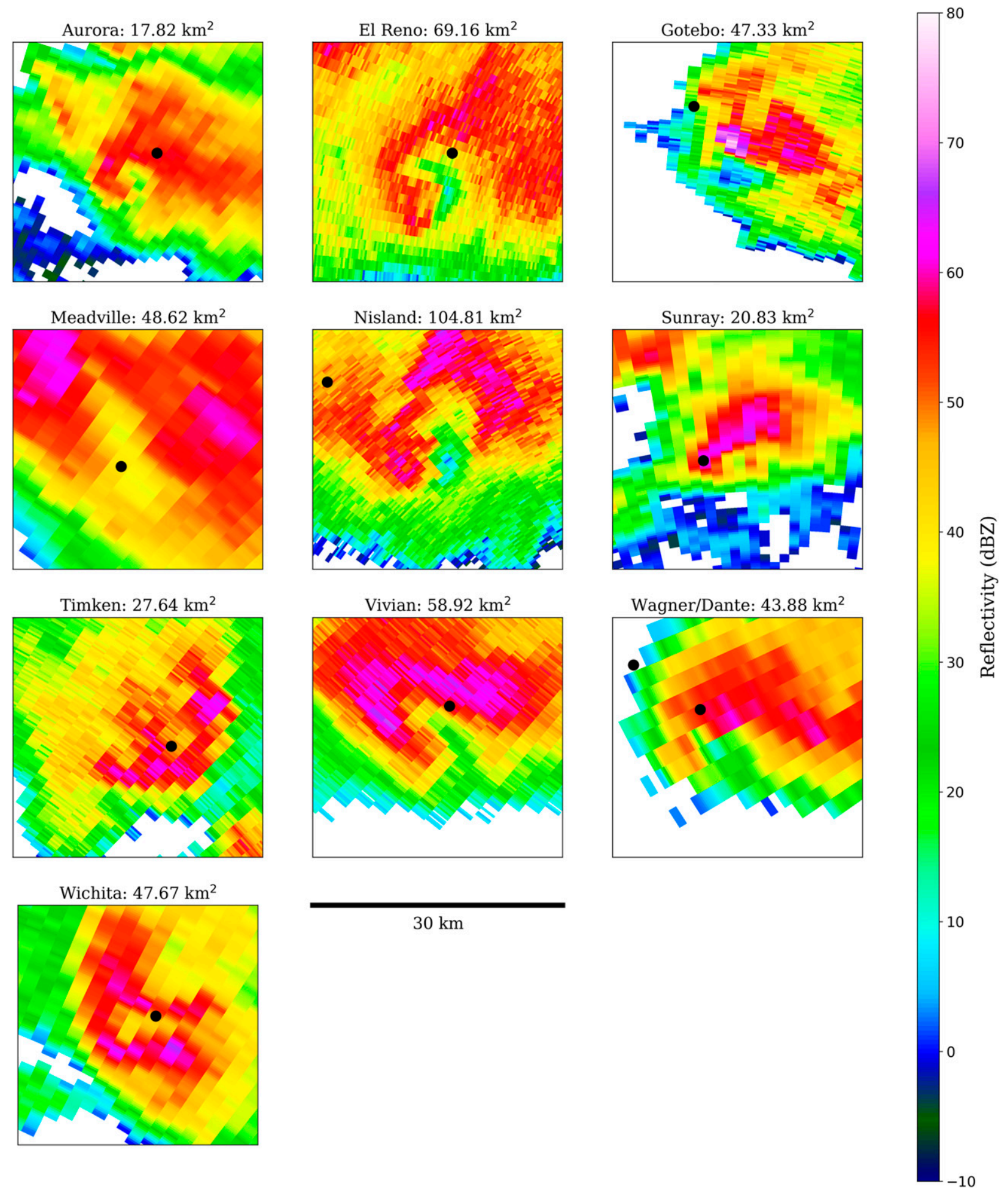

FIG. 13. Examples of the largest BWERs in midlevel $Z_{H}$ scans (elevation angles vary) for each case within the hail growth region. The black dot represents the gargantuan hailfall location. The Argentina BWER is not shown here. The title over each panel indicates the computed BWER area. A length scale is provided in the center column. 
BWER Area as a Function of Time and Height
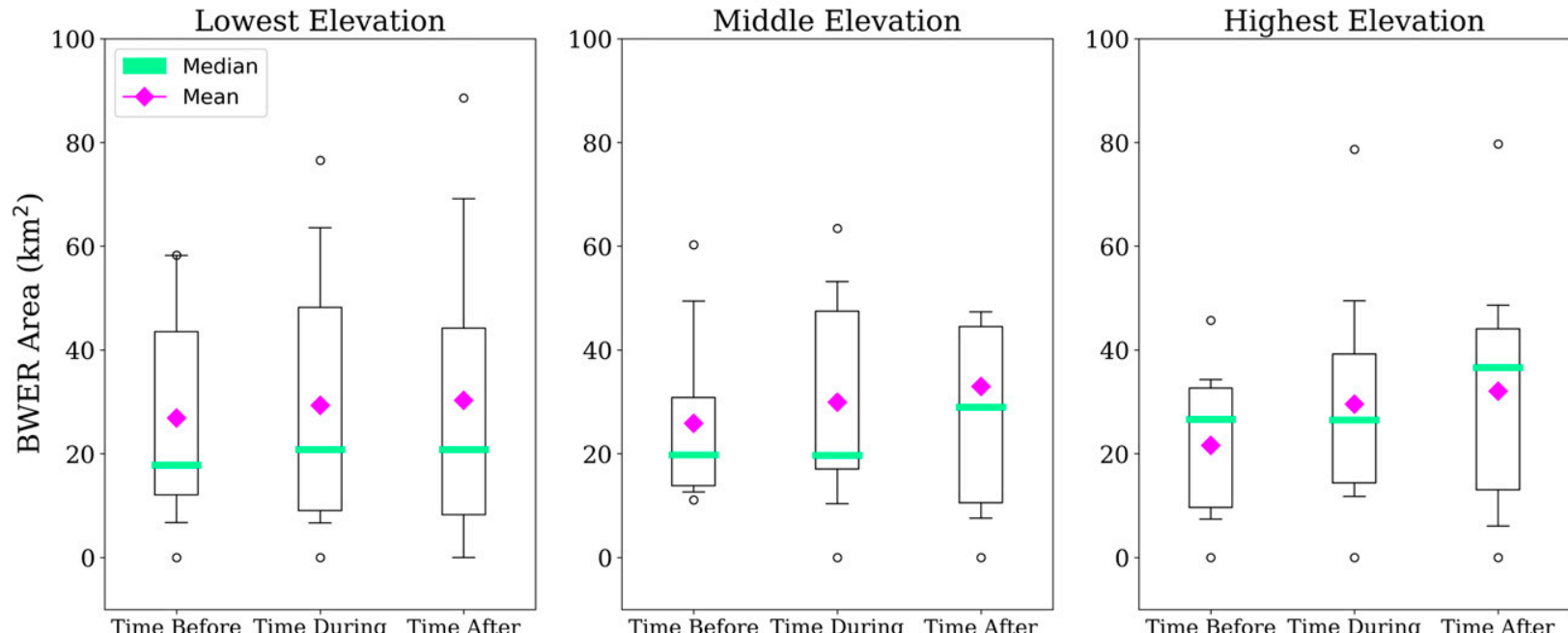

FIG. 14. BWER areas within the hail growth region before, during, and after the gargantuan hailfall. The teal bars are the medians, the magenta diamonds are the means, the boxes are the interquartile range, the whiskers extend to the 10th and 90th percentiles, and the circles are the outliers.

storms are more extreme than those in hailstorms producing smaller maximum sizes.

\section{Conclusions}

In this study, we describe characteristics of the environments and selected radar signatures associated with storms that produced hail in excess of 6 in. $(15 \mathrm{~cm})$ in maximum dimension, or "gargantuan" hail, in an effort to evaluate three working hypotheses: 1) gargantuan hail-producing storms have strong, wide updrafts especially favorable for hail production; 2) to support these favorable updrafts, gargantuan hail-producing storms form in environments with greater instability and vertical wind shear than those of storms producing smaller maximum hail sizes; and 3) given the exceptionally large hail produced in these storms, they exhibit distinctive and extreme radar signatures.

The environments of gargantuan hail-producing storms feature a wide range of most unstable convective available potential energy (MUCAPE) values, all exceeding $2000 \mathrm{~J} \mathrm{~kg}^{-1}$. These values are larger than, though partially overlapped with, the MUCAPE values of environments of storms that resulted in smaller maximum hail size reports (e.g., Johnson and Sugden 2014; Blair et al. 2017; Kumjian et al. 2019). Similarly, the range of values of 0-6-km bulk wind shear are somewhat larger, but overlapped with those of smaller hail size classes. The $0-3-\mathrm{km}$ storm-relative helicity for gargantuan hail cases completely overlapped with those of marginally severe hail (Johnson and Sugden 2014) and even
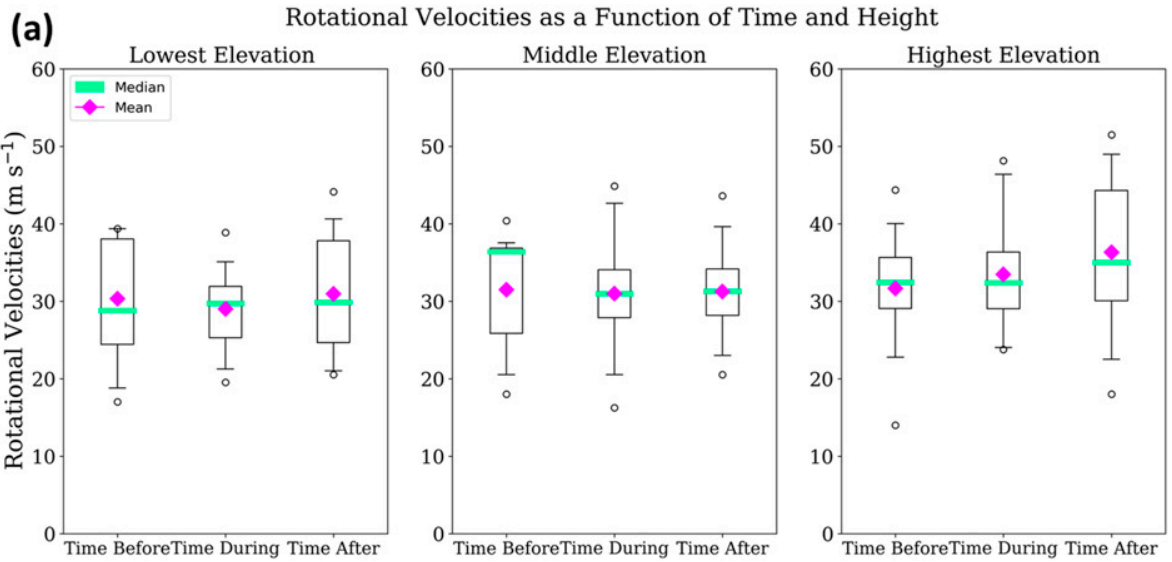

(b)

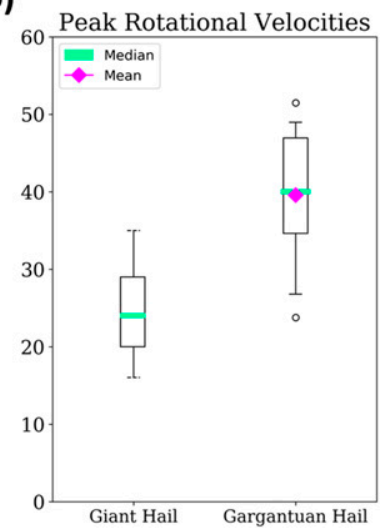

FIG. 15. (a) Rotational velocities within the hail growth region before, during, and after the time of gargantuan hailfall. The teal bars are the medians, the magenta diamonds are the means, the boxes are the interquartile range, the whiskers extend to the 10th and 90th percentiles, and the circles are the outliers. (b) Comparison of Blair et al. (2011) results for hail $\geq 4$ in. $(\geq 10 \mathrm{~cm})$ in maximum dimension (giant hail; left box plot) to our results for hail $\geq 6$ in. ( $\geq 15 \mathrm{~cm}$ ) in maximum dimension (gargantuan hail; right box plot). 
storms that produced large accumulations of small hail (Kumjian et al. 2019). Thus, the environmental analysis is somewhat consistent with our second hypothesis, though the distinction is not particularly clear. The operational significant hail parameter (SHIP), which combines several environmental properties, likewise exhibits significant overlap between gargantuan hail cases and those of smaller hail sizes. These comparisons show that commonly used bulk indices for severe storms forecasting are not helpful in distinguishing hail sizes, and suggests future exploration of more nuanced aspects of the environments. Indeed, analysis of stormrelative hodographs suggests larger magnitudes of storm-relative winds at low levels ( $<2 \mathrm{~km}$ AGL) than storms producing large accumulations of small hail.

Larger storm-relative wind magnitudes at low levels combined with the larger MUCAPE values for the gargantuan hail environments suggests larger updraft widths in gargantuan hail-producing supercells, in support of our first hypothesis. Accounting for the effects of entrainment on updraft properties through ECAPE (Peters et al. 2020a) reveals that gargantuan hail-producing storms seem to be better protected from the deleterious effects of entrainment than a large sample of severe thunderstorms (Peters et al. 2019), which would tend to promote stronger updrafts and larger liquid water contents. These factors would be favorable for more significant hail growth. Using a technique developed here to quantify bounded weak echo region (BWER) area, which we take as a crude proxy for the updraft area, our analysis indeed suggests gargantuan hail-producing storms do have observably wider updrafts, at least compared to simulated supercell storms in recent studies (e.g., Peters et al. 2019). Further analysis of BWER area in other storms with smaller reported maximum hail sizes is suggested for future work.

Radar reflectivity maxima and vertical profiles of radar reflectivity through the gargantuan hail-producing storms did not differ substantially from those reported in the literature for cases of storms producing smaller hail sizes, which is inconsistent with our third hypothesis. Of note, the gargantuan hail report location tended to be displaced from the maximum reflectivity core of the storm. In contrast, we found that radarestimated rotational velocities estimated associated with the mesocyclone within the hail growth region of gargantuan hail cases were substantially larger than those corresponding to cases of giant $(>10 \mathrm{~cm})$ hail reported in Blair et al. (2011). This shows the possible use of Doppler radar to identify supercell hail potential, wherein larger rotational velocities may be indicative of larger maximum hail sizes.

Acknowledgments. This research is funded by the National Science Foundation (NSF) Award AGS 1661679. We thank Dr. John Peters (Naval Postgraduate School) and two additional anonymous reviewers for their thoughtful and constructive reviews, which helped improve the manuscript. Thank you to Dr. Kevin Bowley for insightful discussions and data resources. Thank you to Karly Reimel and Scott Loeffler for assistance with code. This work was part of the first author's master's thesis at the Pennsylvania State University.

Data availability statement. Radar data are freely available from the National Centers for Environmental Information
(NCEI) by NOAA. Data from RMA1 in Argentina were obtained through Professor Paola Salio at the University of Buenos Aires from the Subsecretaria de Recursos Hidricos, Ministerio del Interior, Obras Publicas y Viviendia, Presidencia de la Nacion, Argentina. Hail report data are freely available from the Storm Events Database within NCEI. RAP data are also available through NCEI. Environmental sounding data are freely available from the University of Wyoming. ERA-5 data are freely available from ECMWF.

\section{REFERENCES}

Allen, J. T., M. K. Tippett, and A. H. Sobel, 2015: An empirical model relating U.S. monthly hail occurrence to large-scale meteorological environment. J. Adv. Model. Earth Syst., 7, 226-243, https://doi.org/10.1002/2014MS000397.

,-- Y. Kaheil, A. H. Sobel, C. Lepore, S. Nong, and A. Muehlbauer, 2017: An extreme value model for U.S. hail size. Mon. Wea. Rev., 145, 4501-4519, https://doi.org/10.1175/ MWR-D-17-0119.1.

- I. M. Giammanco, M. R. Kumjian, H. Jurgen Punge, Q. Zhang, P. Groenemeijer, M. Kunz, and K. Ortega, 2020: Understanding hail in the earth system. Rev. Geophys., 58, e2019RG000665, https://doi.org/10.1029/2019RG000665.

Anderson-Frey, A. K., Y. P. Richardson, A. R. Dean, R. L. Thompson, and B. T. Smith, 2016: Investigation of near-storm environments for tornado events and warnings. Wea. Forecasting, 31, 1771-1790, https://doi.org/10.1175/WAF-D-16-0046.1.

Aydin, K., T. A. Seliga, and V. Balaji, 1986: Remote sensing of hail with a dual linear polarization radar. J. Climate Appl. Meteor., 25, 1475-1484, https://doi.org/10.1175/1520-0450(1986)025<1475: RSOHWA $>2.0 . \mathrm{CO} ; 2$.

Bang, S. D., and D. J. Cecil, 2019: Constructing a multifrequency passive microwave hail retrieval and climatology in the GPM domain. J. Appl. Meteor. Climatol., 58, 1889-1904, https:// doi.org/10.1175/JAMC-D-19-0042.1.

Benjamin, S. G., and Coauthors, 2016: A North American hourly assimilation and model forecast cycle: The Rapid Refresh. Mon. Wea. Rev., 144, 1669-1694, https://doi.org/10.1175/MWR-D-150242.1.

Blair, S. F., D. R. Deroche, J. M. Boustead, J. W. Leighton, B. L. Barjenbruch, and W. P. Gargan, 2011: A radar-based assessment of the detectability of giant hail. Electron. J. Severe Storms Meteor, 6 (7), https://www.ejssm.org/ojs/index.php/ ejssm/article/viewArticle/87.

_, and Coauthors, 2017: High-resolution hail observations: Implications for NWS warning operations. Wea. Forecasting, 32, 1101-1119, https://doi.org/10.1175/WAF-D-16-0203.1.

Brown, T. M., W. H. Pogorzelski, and I. M. Giammanco, 2015: Evaluating hail damage using property insurance claims data. Wea. Climate Soc., 7, 197-210, https://doi.org/10.1175/WCASD-15-0011.1.

Browning, K. A., and G. B. Foote, 1976: Airflow and hail growth in supercell storms and some implications for hail suppression. Quart. J. Roy. Meteor. Soc., 102, 499-533, https://doi.org/ 10.1002/qj.49710243303.

Bruick, Z. S., K. L. Rasmussen, and D. J. Cecil, 2019: Subtropical South American hailstorm characteristics and environments. Mon. Wea. Rev., 147, 4289-4304, https://doi.org/10.1175/MWR-D-19-0011.1.

Brunner, C., 2015: Eastern Butte County hit by hail storm. Accessed 10 August 2019, rapidcityjournal.com.

Bryan, G. H., and J. M. Fritsch, 2002: A benchmark simulation for moist nonhydrostatic numerical models. Mon. Wea. Rev., 130, 
2917-2928, https://doi.org/10.1175/1520-0493(2002)130<2917: ABSFMN $>2.0 . \mathrm{CO} ; 2$.

Bunkers, M. J., 2018: Observations of right-moving supercell motion forecast errors. Wea. Forecasting, 33, 145-159, https:// doi.org/10.1175/WAF-D-17-0133.1.

— B. A. Klimowski, J. W. Zeitler, R. L. Thompson, and M. L. Weisman, 2000: Predicting supercell motion using a new hodograph technique. Wea. Forecasting, 15, 61-79, https://doi.org/ 10.1175/1520-0434(2000)015<0061:PSMUAN>2.0.CO;2.

Changnon, S. A., 1999: Data and approaches for determining hail risk in the contiguous United States. J. Appl. Meteor., 38, 1730-1739, https://doi.org/10.1175/1520-0450(1999)038<1730: DAAFDH $>2.0 . \mathrm{CO} ; 2$.

- 2008: Temporal and spatial distributions of damaging hail in the continental United States. Phys. Geogr., 29, 341-350, https://doi.org/10.2747/0272-3646.29.4.341.

Childs, S., 2018: Destructive 2018 hail season a sign of things to come. Colorado State University, accessed 12 August 2019, https://theconversation.com/destructive-2018-hail-season-a-signof-things-to-come-102879.

Cintineo, J. L., T. M. Smith, V. Lakshmanan, H. E. Brooks, and K. L. Ortega, 2012: An objective high-resolution hail climatology of the contiguous United States. Wea. Forecasting, 27, 1235-1248, https://doi.org/10.1175/WAF-D-1100151.1.

Coffer, B. E., and M. D. Parker, 2017: Simulated supercells in nontornadic and tornadic VORTEX2 environments. Mon. Wea. Rev., 145, 149-180, https://doi.org/10.1175/MWR-D-160226.1.

Dennis, E. J., and M. R. Kumjian, 2017: The impact of vertical wind shear on hail growth in simulated supercells. J. Atmos. Sci., 74, 641-663, https://doi.org/10.1175/JAS-D-16-0066.1.

Donaldson, R. J. J., 1961: Radar reflectivity profiles in thunderstorms. J. Meteor., 18, 292-305, https://doi.org/10.1175/15200469(1961)018<0292:RRPIT > 2.0.CO;2.

Doviak, R. J., and D. S. Zrnić, 1993: Doppler Radar and Weather Observations. 2nd ed. Dover Publications, Inc., 562 pp.

Edwards, R., and R. L. Thompson, 1998: Nationwide comparisons of hail size with WSR-88D vertically integrated liquid water and derived thermodynamic sounding data. Wea. Forecasting, 13, 277-285, https://doi.org/10.1175/1520-0434(1998)013<0277: $\mathrm{NCOHSW}>2.0 . \mathrm{CO} ; 2$.

Efron, B., and R. J. Tibshirani, 1993: An Introduction to the Bootstrap. 1st ed. Chapman and Hall, 456 pp.

Foote, G. B., 1984: A study of hail growth utilizing observed storm conditions. J. Climate Appl. Meteor., 23, 84-101, https://doi.org/ 10.1175/1520-0450(1984)023<0084:ASOHGU>2.0.CO;2.

Forster, L., 2019: 2 Colorado hailstorms were among nation's billion-dollar disasters in 2018. Gazette News, 11 February, accessed 12 August 2019.

Geotis, S. G., 1963: Some radar measurements of hailstorms. J. Appl. Meteor., 2, 270-275, https://doi.org/10.1175/15200450(1963)002<0270:SRMOH > 2.0.CO;2.

Giammanco, I. M., T. M. Brown, R. G. Grant, D. L. Dewey, J. D. Hodel, and R. A. Stumpf, 2015: Evaluating the hardness characteristics of hail through compressive strength measurements. J. Atmos. Oceanic Technol., 32, 2100-2113, https:// doi.org/10.1175/JTECH-D-15-0081.1.

Heymsfield, A. J., 1983: Case study of a hailstorm in Colorado. Part IV: Graupel and hail growth mechanisms deduced through particle trajectory calculations. J. Atmos. Sci., 40, 1482-1509, https://doi.org/10.1175/1520-0469(1983)040<1482: CSOAHI $>2.0 . \mathrm{CO} ; 2$.
- I. M. Giammanco, and R. Wright, 2014: Terminal velocities and kinetic energies of natural hailstones. Geophys. Res. Lett., 41, 8666-8672, https://doi.org/10.1002/2014GL062324.

Jewell, R., and J. Brimelow, 2009: Evaluation of Alberta hail growth model using severe hail proximity soundings from the United States. Wea. Forecasting, 24, 1592-1609, https://doi.org/ 10.1175/2009WAF2222230.1.

Johnson, A. W., and K. E. Sugden, 2014: Evaluation of soundingderived thermodynamic and wind-related parameters associated with large hail events. Electron. J. Severe Storms Meteor., 9(5), https:// www.ejssm.org/ojs/index.php/ejssm/article/viewArticle/137.

Knight, C. A., and N. C. Knight, 2005: Very large hailstones from Aurora, Nebraska. Bull. Amer. Meteor. Soc., 86, 1773-1782, https://doi.org/10.1175/BAMS-86-12-1773.

Kumjian, M. R., and K. A. Lombardo, 2020: A hail growth trajectory model for exploring the environmental controls on hail size: Model physics and idealized tests. J. Atmos. Sci., 77, 2765-2791, https://doi.org/10.1175/JAS-D-20-0016.1.

_ Z. J. Lebo, and A. M. Ward, 2019: Storms producing large accumulations of small hail. J. Appl. Meteor. Climatol., 58, 341-364, https://doi.org/10.1175/JAMC-D-18-0073.1.

, and Coauthors, 2020: Gargantuan hail in Argentina. Bull. Amer. Meteor. Soc., 101, E1241-E1258, https://doi.org/10.1175/ BAMS-D-19-0012.1.

Marion, G. R., and R. J. Trapp, 2019: The dynamical coupling of convective updrafts, downdrafts, and cold pools in simulated supercell thunderstorms. J. Geophys. Res. Atmos., 124, 664683, https://doi.org/10.1029/2018JD029055.

Markowski, P., and Y. Richardson, 2010: Mesoscale Meteorology in Midlatitudes. Wiley-Blackwell, $430 \mathrm{pp}$.

May, R., S. Arms, P. Marsh, E. Bruning, and J. Leeman, 2021: Metpy: A Python package for meteorological data. Boulder, CO, accessed 3 June 2019, https://doi.org/10.5065/D6WW7G29, https://github.com/Unidata/MetPy.

Mezher, R. N., M. Doyle, and V. Barros, 2012: Climatology of hail in Argentina. Atmos. Res., 114-115, 70-82, https://doi.org/ 10.1016/j.atmosres.2012.05.020.

Miller, L. J., J. D. Tuttle, and C. A. Knight, 1988: Airflow and hail growth in a severe northern high plains supercell. J. Atmos. Sci., 45, 736-762, https://doi.org/10.1175/1520-0469(1988)045<0736: AAHGIA $>2.0 . \mathrm{CO} ; 2$.

Morrison, H., 2016a: Impacts of updraft size and dimensionality on the perturbation pressure and vertical velocity in cumulus convection. Part I: Simple, generalized analytic solutions. J. Atmos. Sci., 73, 1441-1454, https://doi.org/10.1175/JAS-D15-0040.1.

_ 2016b: Impacts of updraft size and dimensionality on the perturbation pressure and vertical velocity in cumulus convection. Part II: Comparison of theoretical and numerical solutions and fully dynamical simulations. J. Atmos. Sci., 73, 1455-1480, https://doi.org/10.1175/JAS-D-15-0041.1.

MunichRe, 2013: 2013 Natural Catastrophe Year in Review. MunichRe NatCat Services, 92 pp., https://www.iii.org/sites/ default/files/docs/pdf/MunichRe-010714.pdf.

Murillo, E. M., and C. R. Homeyer, 2019: Severe hail fall and hailstorm detection using remote sensing observations. J. Appl. Meteor. Climatol., 58, 947-970, https://doi.org/10.1175/JAMCD-18-0247.1.

Nelson, S. P., 1983: The influence of storm flow structure on hail growth. J. Atmos. Sci., 40, 1965-1983, https://doi.org/10.1175/ 1520-0469(1983)040<1965:TIOSFS > 2.0.CO;2.

_ 1987: The hybrid multicellular-supercellular storm-An efficient hail producer. Part II: General characteristics and 
implications for hail growth. J. Atmos. Sci., 44, 2060-2073, https:// doi.org/10.1175/1520-0469(1987)044<2060:THMSEH> 2.0.CO;2.

Nick, A., T. Lang, J. J. Helmus, and S. Nesbitt, 2016: artview: Artview release 1.2.3. Accessed 2 April 2019, https://doi.org/ 10.5281/zenodo.47224.

NOAA, 2019: NOAA's weather and climate toolkit (viewer and data exporter). NOAA, accessed 5 March 2018, https:// www.ncdc.noaa.gov/wct/.

NOAA/National Centers for Environmental Information, 2019: NCDC storm events database: Storm events data. NOAA, accessed 3 November 2017, https://data.nodc.noaa.gov/cgibin/iso?id=gov.noaa.ncdc:C00510\#.

NOAA/NWS, 2007: Very large hail from Dante, SD-August 21, 2007. U.S. Department of Commerce, NOAA/National Weather Service, accessed 3 June 2019, https://www.weather.gov/ fsd/20070821-hail-dante.

_ 2010a: Record setting hail event in Vivian, South Dakota on July 23, 2010. U.S. Department of Commerce, NOAA/ National Weather Service, accessed 3 June 2019, https:// www.weather.gov/abr/vivianhailstone.

_ 2010b: September 15th 2010 record setting hail. U.S. Department of Commerce, NOAA/National Weather Service, accessed 3 June 2019, https://www.weather.gov/ict/event.

Ortega, K. L., 2018: Evaluating multi-radar, multi-sensor products for surface hail-fall diagnosis. Electron. J. Severe Storms Meteor, 13 (1), https://ejssm.org/ojs/index.php/ejssm/article/ viewArticle/163.

Parker, M. D., 2010: Relationship between system slope and updraft intensity in squall lines. Mon. Wea. Rev., 138, 3572-3578, https://doi.org/10.1175/2010MWR3441.1.

— , 2014: Composite VORTEX2 supercell environments from near-storm soundings. Mon. Wea. Rev., 142, 508-529, https:// doi.org/10.1175/MWR-D-13-00167.1.

Peel, S., and L. J. Wilson, 2008: Modeling the distribution of precipitation forecasts from the Canadian ensemble prediction system using kernel density estimation. Wea. Forecasting, 23, 575-595, https://doi.org/10.1175/2007WAF2007023.1.

Peters, J. M., 2020: Are supercells resistant to entrainment because of their rotation? J. Atmos. Sci., 77, 1475-1495, https://doi.org/ 10.1175/JAS-D-19-0316.1.

— C. J. Nowotarski, and H. C. Morrison, 2019: The role of vertical wind shear in modulating maximum supercell updraft velocities. J. Atmos. Sci., 76, 3169-3189, https://doi.org/10.1175/ JAS-D-19-0096.1.

— , H. C. Morrison, C. J. Nowotarski, J. P. Mulholland, and R. L. Thompson, 2020a: A formula for the maximum vertical velocity in supercell updrafts. J. Atmos. Sci., 77, 3747-3757, https://doi.org/10.1175/JAS-D-20-0103.1.

,,,,---- and,$- 2020 \mathrm{~b}$ : The influences of effective inflow layer streamwise vorticity and storm-relative flow on supercell updraft properties. J. Atmos. Sci., 77, 3033-3057, https://doi.org/10.1175/JAS-D-19-0355.1.

Púčik, T., P. Groenemeijer, D. Rýva, and M. Kolář, 2015: Proximity soundings of severe and nonsevere thunderstorms in central Europe. Mon. Wea. Rev., 143, 4805-4821, https:// doi.org/10.1175/MWR-D-15-0104.1.
Rasmussen, R. M., and A. J. Heymsfield, 1987: Melting and shedding of graupel and hail. Part III: Investigation of the role of shed drops as hail embryos in the 1 August CCOPE severe storm. J. Atmos. Sci., 44, 2783-2803, https://doi.org/10.1175/ 1520-0469(1987)044<2783:MASOGA > 2.0.CO;2.

Roeder, P. E., 2012: Severe Weather in North America: Perils, Risks, and Insurance. Knowledge Series: Natural Hazards, Munich RE, 274 pp.

Ryzhkov, A. V., T. J. Schuur, D. W. Burgess, P. L. Heinselman, S. E. Giangrande, and D. S. Zrnić, 2005: The Joint Polarization Experiment polarimetric rainfall measurements and hydrometeor classification. Bull. Amer. Meteor. Soc., 86, 809-824, https://doi.org/10.1175/BAMS-86-6-809.

Storm Prediction Center, 2019: Help-Significant hail parameter. Accessed 20 July 2019, https://www.spc.noaa.gov/ exper/mesoanalysis/help/help.

Taszarek, M., H. E. Brooks, and B. Czernecki, 2017: Soundingderived parameters associated with convective hazards in Europe. Mon. Wea. Rev., 145, 1511-1528, https://doi.org/ 10.1175/MWR-D-16-0384.1.

Tessendorf, S. A., L. J. Miller, K. C. Wiens, and S. A. Rutledge, 2005: The 29 June 2000 supercell observed during STEPS. Part I: Kinematics and microphysics. J. Atmos. Sci., 62, 4127-4150, https://doi.org/10.1175/JAS3585.1.

Torres, K., 2018: Cheyenne Mountain Zoo reopens after hail damages buildings, kills several animals. FOX 31 Denver, 10 August 2018, https://kdvr.com/on-air/on-channel-2/cheyenne-mountain-zooto-reopen-after-hail-damages-buildings-kills-several-animals/.

Trapp, R. J., G. R. Marion, and S. W. Nesbitt, 2017: The regulation of tornado intensity by updraft width. J. Atmos. Sci., 74, 41994211, https://doi.org/10.1175/JAS-D-16-0331.1.

Warren, R. A., H. Richter, H. A. Ramsay, S. T. Siems, and M. J. Manton, 2017: Impact of variations in upper-level shear on simulated supercells. Mon. Wea. Rev., 145, 2659-2681, https:// doi.org/10.1175/MWR-D-16-0412.1.

Weather Forecast Office San Antonio, 2016: Austin/San Antonio Weather Forecast Office, Weather event summary: San Antonio April 2016. NOAA/NWS, 5 pp., https://www.weather.gov/media/ ewx/wxevents/ewx-20160412.pdf.

Weisman, M. L., R. Rotunno, M. L. Weisman, and R. Rotunno, 2000: The use of vertical wind shear versus helicity in interpreting supercell dynamics. J. Atmos. Sci., 57, 1452-1472, https://doi.org/ 10.1175/1520-0469(2000)057<1452:TUOVWS >2.0.CO;2.

Witt, A., 1998: The relationship between WSR-88D measured midlatitude rotation and maximum hail size. Preprints, 19th Conf. on Severe Local Storms, Minneapolis, MN, Amer. Meteor. Soc., 740-743.

- D. W. Burgess, A. Seimon, J. T. Allen, J. C. Snyder, and H. B. Bluestein, 2018: Rapid-scan radar observations of an Oklahoma tornadic hailstorm producing giant hail. Wea. Forecasting, 33, 1263-1282, https://doi.org/10.1175/WAF-D-18-0003.1.

Zhang, G. J., 2009: Effects of entrainment on convective available potential energy and closure assumptions in convection parameterization. J. Geophys. Res., 114, D07109, https://doi.org/ 10.1029/2008JD010976.

Ziegler, C. L., P. S. Ray, and N. C. Knight, 1983: Hail growth in an Oklahoma multicell storm. J. Atmos. Sci., 40, 1768-1791, https:// doi.org/10.1175/1520-0469(1983)040<1768:HGIAOM>2.0.CO;2. 